\title{
Chemical Kinetic Study on Dual-Fuel Combustion: The Ignition Properties of n-Dodecane/Methane Mixture
}

\author{
Weijian Zhou (iD, Song Zhou (iD, Hongyuan Xi (D), Majed Shreka, and Zhao Zhang \\ College of Power and Energy Engineering, Harbin Engineering University, Harbin 150001, China \\ Correspondence should be addressed to Song Zhou; songzhouheu@163.com
}

Received 10 June 2021; Revised 25 August 2021; Accepted 25 October 2021; Published 22 November 2021

Academic Editor: Valeria Di Sarli

Copyright (C) 2021 Weijian Zhou et al. This is an open access article distributed under the Creative Commons Attribution License, which permits unrestricted use, distribution, and reproduction in any medium, provided the original work is properly cited.

\begin{abstract}
The natural gas (NG)/diesel dual-fuel engine has attracted extensive attention in recent years, and the influence of ignition delay on the engine is very important. Therefore, the research on the ignition delay of NG/diesel dual fuel is of great significance. In this work, a simplified n-dodecane mechanism was used to study the effect of methane mixture ratio on the n-dodecane ignition process. The results showed that the ignition delay time increased with the increase of methane content by changing the mixing ratio of methane and $\mathrm{n}$-dodecane. However, the effect of methane on the ignition delay time gradually decreases when the content of the $\mathrm{n}$-dodecane mixing ratio is greater than $50 \%$. It was also found that with the increase of $\mathrm{n}$-dodecane content, the reduction degree of the ignition delay time of the whole reaction system decreased and the negative temperature coefficient (NTC) behavior increased. Moreover, when the initial pressure increased from 20 bar to 60 bar, the thermal effect of methane also increases from $7.03 \%$ to $9.55 \%$. The relationship between ignition characteristics of methane-n-dodecane and temperature was studied by changing the initial temperature. Furthermore, the evolution of species in the ignition process of the whole reaction system was analyzed, and the decomposition of n-dodecane first occurs in the reaction n- $\mathrm{C}_{12} \mathrm{H}_{26}+\mathrm{O}_{2}=\mathrm{R}+\mathrm{HO}_{2}$ to form $\mathrm{R}$ and free radicals; however, the reaction $\mathrm{CH}_{4}+\mathrm{OH}=\mathrm{CH}_{3}+\mathrm{H}_{2} \mathrm{O}$ dominates with the increase of the methane mixing ratio and inhibits the ignition process. Through the analysis of reaction paths, sensitivity, and rates of production and consumption of methane/n-dodecane, it was explained how $\mathrm{n}$-dodecane accelerates methane ignition through the rapidly formed free radicals.
\end{abstract}

\section{Introduction}

With the increasingly severe energy situation and environmental crisis, the engine emission regulations are becoming more and more strict and the research of alternative fuel has attracted more attention. At present, the main alternative fuels for internal combustion engines are NG [1], methanol [2-4], ethanol [5], hydrogen [6], etc. Among many alternative fuels, NG is one of the most widely used alternative fuels in internal combustion engines. Compared with diesel and gasoline, NG is a clean alternative fuel for engines, which is almost free of sulfur, dust, and other harmful substances. Besides, NG has abundant reserves that have been widely the subject of interest by the international community [7]. Because the main component of NG is methane with high octane number, which has good antiknock performance, the diesel pilot ignition NG engine can operate at a high compression ratio so that its thermal efficiency can reach the level of a diesel engine and its power performance is guaranteed $[8,9]$. NG can be used in the high-reactivity fuel ignition dual-fuel engine and reactivity controlled compression ignition (RCCI) engine [10]. Compared with the traditional diesel engine, the combustion temperature of the NG engine is significantly lower, which greatly reduces the emissions of soot and nitrogen oxides (NOx) [11-13]. In addition, the whole diesel/NG mixture is an excessively thin mixture, and the compression ratio can be improved by eliminating the auto-ignition behavior of the end gas [14].

The combustion strategy of dual-fuel engines is more complex than that of pure diesel engines, which has been the focus of researchers $[15,16]$. Cordiner et al. [17] studied the combustion and emission characteristics of dual-fuel engines by means of experiments and numerical simulation. 
They found that the dual-fuel engines could reduce particulate matter (PM) and NOx emissions, but hydrocarbons (HC) and carbon monoxide (CO) emissions increased under dilute combustion conditions. The analysis of the influence of each control parameter on the engine performance is helpful to the development of a high-performance dual-fuel engine-including injection strategy, exhaust gas recirculation (EGR) rate [18], and substitution rate [19, 20]. Abagnale et al. [21] studied the performance of the NG/ diesel dual-fuel engine through six different fuel combinations experiments. The results showed that the maximum burst pressure, the maximum temperature, and the NOx emission in the cylinder increased with the increase of the methane substitution ratio. Sunmeet et al. [22] tested and studied the combustion and emission performance of diesel/ NG RCCI engines. They studied the different NG substitution rates and analyzed the combustion and emission characteristics of the traditional dual-fuel mode and RCCI mode by changing the exhaust gas recirculation (EGR) rate. The results showed that with the increase of EGR rate, NOx emission decreased significantly but smoke increased significantly. Besides, EGR could reduce $\mathrm{CO}$ and $\mathrm{HC}$ emissions of RCCI engines under partial load.

There are two main working modes of the diesel/NG dual-fuel engine, namely pure diesel mode and dual-fuel mode. The delayed ignition time of pure diesel mode is less than that of dual-fuel mode [23-25]. For the diesel pilot ignition NG dual-fuel engine, the factors affecting the ignition delay of diesel and NG mixture are very complex and it is difficult to find out in the test case. Therefore, it is necessary to study the chemical kinetic ignition characteristics of methane/n-dodecane mixtures with different mixing ratios. The actual NG and diesel fuels are complex mixtures. Therefore, in order to facilitate theoretical research, only methane is taken into consideration, while other components of NG were ignored [26]. Therefore, methane is generally used as an alternative fuel for NG. There are several hundred main components of diesel including cycloalkanes, straight-chain alkanes, and aromatic hydrocarbons [27]. Because the molecular size of $n$-dodecane is close to that of ordinary diesel, it has recently been used as an alternative fuel to simulate diesel combustion [28-31]. The main physical and chemical characteristics of n-dodecane and methane are shown in Table 1. At present, there are few numerical studies on methane-n-dodecane dual fuel. Fu and Aggarwal [32] studied the effect of methane on the ignition of $n$-heptane. However, the effect of methane on the ignition delay of $n$-heptane has not been systematically analyzed. Tekgül et al. [33] used large eddy simulation to study the spray ignition characteristics of methane and n-dodecane dual fuel. They found that methane prolonged the ignition delay of $\mathrm{n}$-dodecane. However, the interaction between methane and n-dodecane and the effect of methane concentration on ignition delay are not explained. Kahila et al. $[34,35]$ numerically studied the ignition process of $\mathrm{n}$-dodecane in lean methane-air mixture under engine-related conditions. They studied pilot spray ignition problem under fixed mass injection rate and different injection durations and compared two simplified $\mathrm{n}$-dodecane reaction
TABLE 1: Selected fuel properties.

\begin{tabular}{lcc}
\hline Fuel & n-Dodecane & Methane \\
\hline Chemical formula & $\mathrm{n}-\mathrm{C}_{12} \mathrm{H}_{26}$ & $\mathrm{CH}_{4}$ \\
Molecular weight $(\mathrm{g} / \mathrm{mol})$ & 170.33 & 16.04 \\
$\mathrm{H} / \mathrm{C}$ ratio & 2.1667 & 4 \\
Density (g/L) & 749.5 & 0.71 \\
Lower heating value $(\mathrm{MJ} / \mathrm{kg})$ & 44.147 & 50.0 \\
Boiling point $(\mathrm{K})$ & 489.3 & 111.66 \\
\hline
\end{tabular}

mechanisms and the effects of different diesel pilot spray quantities on the ignition characteristics of $\mathrm{n}$-dodecane in a methane environment. However, only the methane content remains unchanged, and the effect of methane concentration on $\mathrm{n}$-dodecane is not considered.

In this study, the ignition delay phenomenon of diesel/ NG dual-fuel combustion was analyzed by chemical kinetics. The core of this study is to understand the oxidation of n-dodecane and methane. Firstly, many researchers have studied the chemical kinetic mechanism of methane. Khan et al. [36] compared the San Diego [37], the GRI-Mech 3.0 [38], and the USC-Mech 2.0 [39] mechanisms. The research results showed that the GRI-Mech 3.0 mechanism has the best prediction effect on the laminar flame speed of methane-hydrogen blend. Gimeno-Escobedo et al. [40] studied the reduced methane-hydrogen mixtures mechanism from the GRI-Mech 3.0 mechanism. The results showed that validation for zero-dimensional and one-dimensional calculations have a small error between the predicted and original mechanism. Besides, the mechanism was applicable to a variety of methane-hydrogen mixtures. However, in the detailed Lawrence Livermore National Laboratory (LLNL) [41] n-dodecane mechanism, the species and reaction of C1$\mathrm{C} 3$ can be used to describe the oxidation process of methane. Therefore, other chemical kinetic mechanisms of methane are not selected in this work. In this contribution, the detailed LLNL mechanism was preliminarily simplified, most of the components and reactions were retained, and the ignition delay of methane-n-dodecane was analyzed in detail. Moreover, the simulation included different initial temperatures and different mixing ratios of methane and $\mathrm{n}$-dodecane to consider different engine operating conditions. Finally, reaction path analysis, sensitivity analysis, and rate of production analysis were carried out to explain the characteristics of dual-fuel ignition.

\section{Simulation Methods}

2.1. Mechanism and Kinetic Model Development. Methane is one of the important intermediates in the ignition process of $n$-dodecane so the oxidation mechanism of $\mathrm{n}$-dodecane has included the submechanism of methane oxidation, which can be used as the chemical kinetic model of the mixture. The LLNL mechanism is considered to be one of the most detailed chemical kinetic mechanisms describing the oxidation of $n$-dodecane, consisting of 2885 species and 11,754 reactions. The $\mathrm{n}$-dodecane mechanism reduction was performed using the direct relation graph (DRG) [42] and the directed relation graph with error propagation (DRGEP) 
[43]. ANSYS CHEMKIN Reaction Workbench software was used to conduct the reduced mechanism [44]. In order to obtain a more accurate and simple mechanism to describe the oxidation process and ignition characteristics as accurate as possible, a new simplified chemical kinetic mechanism of $\mathrm{n}$-dodecane and methane dual fuel has been developed in this paper. This new reduced mechanism is based on the Lawrence Livermore National Laboratory (LLNL) mechanism. First, the LLNL mechanism was simplified by specifying the evaluation criterion was specified as an initial set of components including reactants $\left(\mathrm{CH}_{4}, \mathrm{n}-\mathrm{C}_{12} \mathrm{H}_{26}\right.$, and $\left.\mathrm{O}_{2}\right)$, products $\left(\mathrm{CO}_{2}\right.$, and $\left.\mathrm{H}_{2} \mathrm{O}\right)$, and important intermediate products $\left(\mathrm{CH}_{2} \mathrm{O}, \mathrm{CH}_{3}, \mathrm{CO}\right.$, and $\left.\mathrm{H}_{2} \mathrm{O}_{2}\right)$. Considering the important role of free radicals in the mixed system, $\mathrm{H}, \mathrm{O}$, and $\mathrm{OH}$ were also added as the initial important components, and the ignition delay time was selected as the target. The reduction was performed at a pressure of 1-60 atm, an initial temperature of $700-1600 \mathrm{~K}$, and an equivalence ratio of $0.5-1.5$. The reduced mechanism based on the above simplification methods consisted of 526 species and 2551 reactions. Because this paper only analyzes the influence of methane content on the ignition characteristics of $\mathrm{n}$-dodecane, a simple reduced step is carried out. In this case, the key species and related reaction pathway are retained, and the accuracy is not much lost.

2.2. Model Validation. The ignition delay time was predicted using the CHEMKIN package simulation data [45]. The problem type was used to constrain the volume and solve the energy equation with the closed homogeneous model that calculates the ignition delay time. The ignition delay time was defined as the time when the initial temperature of the fuel increases by $400 \mathrm{~K}$. Figure 1 shows the comparison between the detailed mechanism and the 526 species mechanism ignition delay times of $\mathrm{n}$-dodecane at pressures of 20 bar and equivalence ratio of 0.5 and 1.0. The 526 species mechanism is in good agreement with the detailed mechanism and experimental data of Vasu et al. [46].

The premixed laminar flame speed calculator models of the CHEMKIN software package are used to simulate the laminar flame speed of $\mathrm{n}$-dodecane. Figure 2 shows the laminar flame speed of 526 species at an equivalence ratio of $0.6-1.5$, atmospheric pressure, and unburned fuel temperatures of 403 and $470 \mathrm{~K}$. Compared with the experimental data of Kumar and Sung [47], Ji et al. [48], and Hui and Sung [49], it can be seen that the prediction of laminar flame speed is very good.

For the ignition of methane as a single fuel, Table 2 lists the 33 most important reactions of methane in the combustion process compiled by Manias et al. [50] and analyzes the effect of adding stable intermediate products $\mathrm{CH}_{2} \mathrm{O}$ and $\mathrm{H}_{2} \mathrm{O}_{2}$ on fuel auto-ignition. These two intermediate components are produced by the low-temperature reaction in the $\mathrm{n}$-dodecane mixture. It can be seen from Table 2 that the simplified mechanism includes all reactions. In a dual-fuel engine, the methane/air mixture operates at an equivalence ratio below 1.0. In order to evaluate the methane oxidation performance, Figure 3 compares ignition delay times of the reduced mechanism simulation results with the

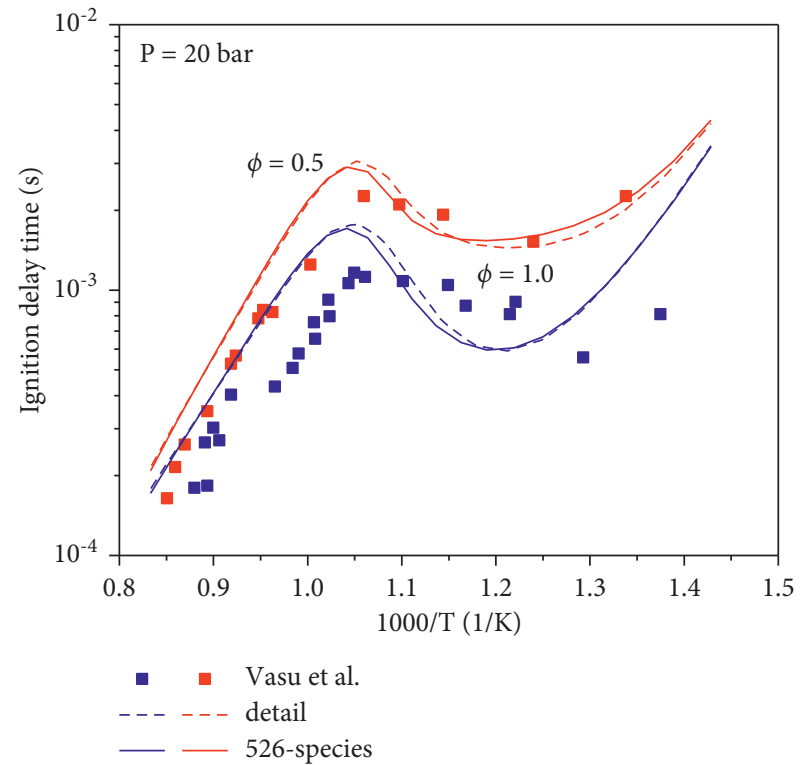

FIgure 1: Ignition delay times validation for $\mathrm{n}$-dodecane. The experimental data used for comparison were taken from Vasu et al. [46].

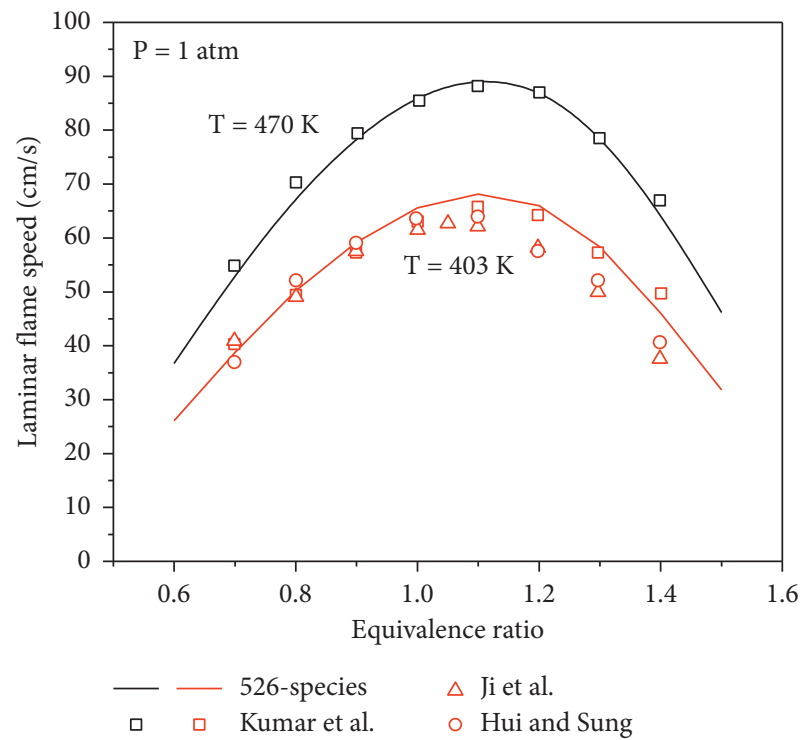

FIgURE 2: Laminar flame speed validation for n-dodecane at an equivalence ratio of $0.6-1.5$, atmospheric pressure, and unburned fuel temperatures of 403 and $470 \mathrm{~K}$. The experimental data used for comparison were taken from Kumar and Sung [47], Ji et al. [48], and Hui and Sung [49].

experimental data of Petersen et al. [51] at initial pressures of 50 bar and 150 bar. At the same time, the Aramcol.3 [52] mechanism is also used as a reference result. Figure 3 shows that the reduced mechanism can well predict these trends.

Figure 4 shows the laminar flame speed of 526 species and Aramcol.3 mechanisms at atmospheric pressure and an unburned fuel temperature of $T=300 \mathrm{~K}$. Compared with the experimental data of $\mathrm{Gu}$ et al. [53] and Rozenchan et al. [54], it can be seen that the prediction of laminar flame speed is very good. 
TABLE 2: The important reactions of the methane ignition process.

\begin{tabular}{|c|c|c|}
\hline & Reaction & Reduced mechanism \\
\hline 1 & $\mathrm{H}+\mathrm{O}_{2} \longleftrightarrow \mathrm{O}+\mathrm{OH}$ & $\checkmark(\longleftrightarrow)$ \\
\hline 2 & $\mathrm{O}+\mathrm{H}_{2} \longleftrightarrow \mathrm{H}+\mathrm{OH}$ & $\checkmark(\longleftrightarrow)$ \\
\hline 3 & $\mathrm{OH}+\mathrm{H}_{2} \longleftrightarrow \mathrm{H}+\mathrm{H}_{2} \mathrm{O}$ & $\checkmark(\longleftrightarrow)$ \\
\hline $4 \mathrm{f}$ & $\mathrm{H}+\mathrm{OH}(+\mathrm{M}) \longrightarrow \mathrm{H}_{2} \mathrm{O}(+\mathrm{M})$ & $\checkmark(\longleftrightarrow)$ \\
\hline $5 f$ & $\mathrm{H}+\mathrm{O}_{2}(+\mathrm{M}) \longrightarrow \mathrm{HO}_{2}(+\mathrm{M})$ & $\checkmark(\longleftrightarrow)$ \\
\hline $6 f$ & $\mathrm{HO}_{2}+\mathrm{OH} \longrightarrow \mathrm{H}_{2} \mathrm{O}+\mathrm{O}_{2}$ & $\checkmark(\longleftrightarrow)$ \\
\hline $7 f$ & $\mathrm{HO}_{2}+\mathrm{HO}_{2} \longrightarrow \mathrm{H}_{2} \mathrm{O}_{2}+\mathrm{O}_{2}$ & $\checkmark(\longleftrightarrow)$ \\
\hline $8 \mathrm{f}$ & $\mathrm{H}_{2} \mathrm{O}_{2}(+\mathrm{M}) \longrightarrow \mathrm{OH}+\mathrm{OH}(+\mathrm{M})$ & $\checkmark(\longleftrightarrow)$ \\
\hline 9f & $\mathrm{H}_{2} \mathrm{O}_{2}+\mathrm{OH} \longrightarrow \mathrm{H}_{2} \mathrm{O}+\mathrm{HO}_{2}$ & $\checkmark(\longleftrightarrow)$ \\
\hline $10 \mathrm{f}$ & $\mathrm{CO}+\mathrm{OH} \longrightarrow \mathrm{CO}_{2}+\mathrm{H}$ & $\checkmark(\longleftrightarrow)$ \\
\hline $11 f$ & $\mathrm{HCO}+\mathrm{O}_{2} \longrightarrow \mathrm{CO}+\mathrm{HO}_{2}$ & $\checkmark(\longleftrightarrow)$ \\
\hline $12 \mathrm{f}$ & $\mathrm{CH}_{2} \mathrm{O}+\mathrm{O}_{2} \longrightarrow \mathrm{HCO}+\mathrm{HO}_{2}$ & $\checkmark(\longleftrightarrow)$ \\
\hline $13 \mathrm{f}$ & $\mathrm{CH}_{2} \mathrm{O}+\mathrm{OH} \longrightarrow \mathrm{HCO}+\mathrm{H}_{2} \mathrm{O}$ & $\checkmark(\longleftrightarrow)$ \\
\hline $14 \mathrm{f}$ & $\mathrm{CH}_{2} \mathrm{O}+\mathrm{CH}_{3} \longrightarrow \mathrm{HCO}+\mathrm{CH}_{4}$ & $\checkmark(\longleftrightarrow)$ \\
\hline $15 f$ & $\mathrm{CH}_{2} \mathrm{O}+\mathrm{HO}_{2} \longrightarrow \mathrm{HCO}+\mathrm{H}_{2} \mathrm{O}_{2}$ & $\checkmark(\longleftrightarrow)$ \\
\hline $16 f$ & $\mathrm{CH}_{3} \mathrm{O}(+\mathrm{M}) \longrightarrow \mathrm{CH}_{2} \mathrm{O}+\mathrm{H}(+\mathrm{M})$ & $\checkmark(\longleftrightarrow)$ \\
\hline $17 f$ & $\mathrm{CH}_{3} \mathrm{O}+\mathrm{O}_{2} \longrightarrow \mathrm{CH}_{2} \mathrm{O}+\mathrm{HO}_{2}$ & $\checkmark(\longleftrightarrow)$ \\
\hline $18 \mathrm{f}$ & $\mathrm{CH}_{3}+\mathrm{H}(+\mathrm{M}) \longrightarrow \mathrm{CH}_{4}(+\mathrm{M})$ & $\checkmark(\longleftrightarrow)$ \\
\hline 19 & $\mathrm{CH}_{4}+\mathrm{H} \longleftrightarrow \mathrm{CH}_{3}+\mathrm{H}_{2}$ & $\checkmark(\longleftrightarrow)$ \\
\hline $20 f$ & $\mathrm{CH}_{4}+\mathrm{OH} \longrightarrow \mathrm{CH}_{3}+\mathrm{H}_{2} \mathrm{O}$ & $\checkmark(\longleftrightarrow)$ \\
\hline $21 \mathrm{f}$ & $\mathrm{CH}_{4}+\mathrm{HO}_{2} \longrightarrow \mathrm{CH}_{3}+\mathrm{H}_{2} \mathrm{O}_{2}$ & $\checkmark(\longleftrightarrow)$ \\
\hline $22 \mathrm{f}$ & $\mathrm{CH}_{3}+\mathrm{HO}_{2} \longrightarrow \mathrm{CH}_{3} \mathrm{O}+\mathrm{OH}$ & $\checkmark(\longleftrightarrow)$ \\
\hline 23 & $\mathrm{CH}_{3}+\mathrm{HO}_{2} \longleftrightarrow \mathrm{CH}_{4}+\mathrm{O}_{2}$ & $\checkmark(\longleftrightarrow)$ \\
\hline $24 \mathrm{f}$ & $\mathrm{CH}_{3}+\mathrm{O}_{2} \longrightarrow \mathrm{CH}_{2} \mathrm{O}+\mathrm{OH}$ & $\checkmark(\longleftrightarrow)$ \\
\hline 25 & $\mathrm{CH}_{3}+\mathrm{O}_{2}(+\mathrm{M}) \longleftrightarrow \mathrm{CH}_{3} \mathrm{O}_{2}(+\mathrm{M})$ & $\checkmark(\longleftrightarrow)$ \\
\hline $26 f$ & $\mathrm{CH}_{3} \mathrm{O}_{2}+\mathrm{CH}_{2} \mathrm{O} \longrightarrow \mathrm{CH}_{3} \mathrm{O}_{2} \mathrm{H}+\mathrm{HCO}$ & $\checkmark(\longleftrightarrow)$ \\
\hline $27 f$ & $\mathrm{CH}_{3} \mathrm{O}_{2}+\mathrm{CH}_{4} \longrightarrow \mathrm{CH}_{3}+\mathrm{CH}_{3} \mathrm{O}_{2} \mathrm{H}$ & $\checkmark(\longleftrightarrow)$ \\
\hline $28 f$ & $\mathrm{CH}_{3} \mathrm{O}_{2}+\mathrm{CH}_{3} \longrightarrow \mathrm{CH}_{3} \mathrm{O}+\mathrm{CH}_{3} \mathrm{O}$ & $\checkmark(\longleftrightarrow)$ \\
\hline $29 f$ & $\mathrm{CH}_{3} \mathrm{O}_{2}+\mathrm{HO}_{2} \longrightarrow \mathrm{CH}_{3} \mathrm{O}_{2} \mathrm{H}+\mathrm{O}_{2}$ & $\checkmark(\longleftrightarrow)$ \\
\hline $30 f$ & $\mathrm{CH}_{3} \mathrm{O}_{2}+\mathrm{OH} \longrightarrow \mathrm{CH}_{3} \mathrm{OH}+\mathrm{O}_{2}$ & $\checkmark(\longleftrightarrow)$ \\
\hline $31 \mathrm{f}$ & $\mathrm{CH}_{3} \mathrm{O}_{2} \mathrm{H} \longrightarrow \mathrm{CH}_{3} \mathrm{O}+\mathrm{OH}$ & $\checkmark(\longleftrightarrow)$ \\
\hline $32 f$ & $\mathrm{CH}_{3}+\mathrm{CH}_{3}(+\mathrm{M}) \longrightarrow \mathrm{C}_{2} \mathrm{H}_{6}(+\mathrm{M})$ & $\checkmark(\longleftrightarrow)$ \\
\hline $33 \mathrm{f}$ & $\mathrm{C}_{2} \mathrm{H}_{4}+\mathrm{OH} \longrightarrow \mathrm{C}_{2} \mathrm{H}_{3}+\mathrm{H}_{2} \mathrm{O}$ & $\checkmark(\longleftrightarrow)$ \\
\hline
\end{tabular}

$(\longleftrightarrow)$ stands for the reversible reaction.

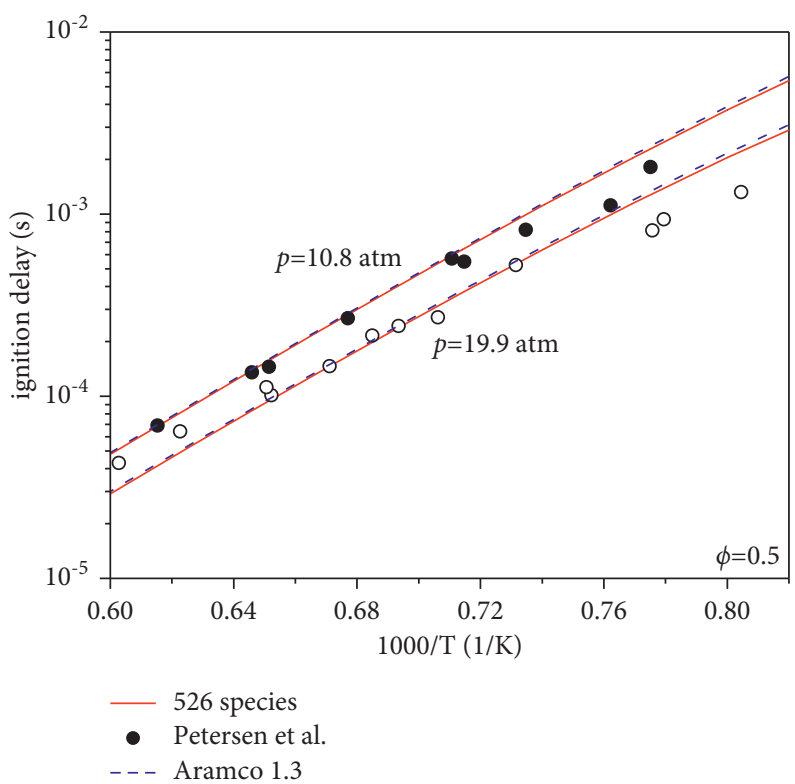

Figure 3: Ignition delay times validation for methane. The experimental data used for comparison were taken from Petersen et al. [51]. 


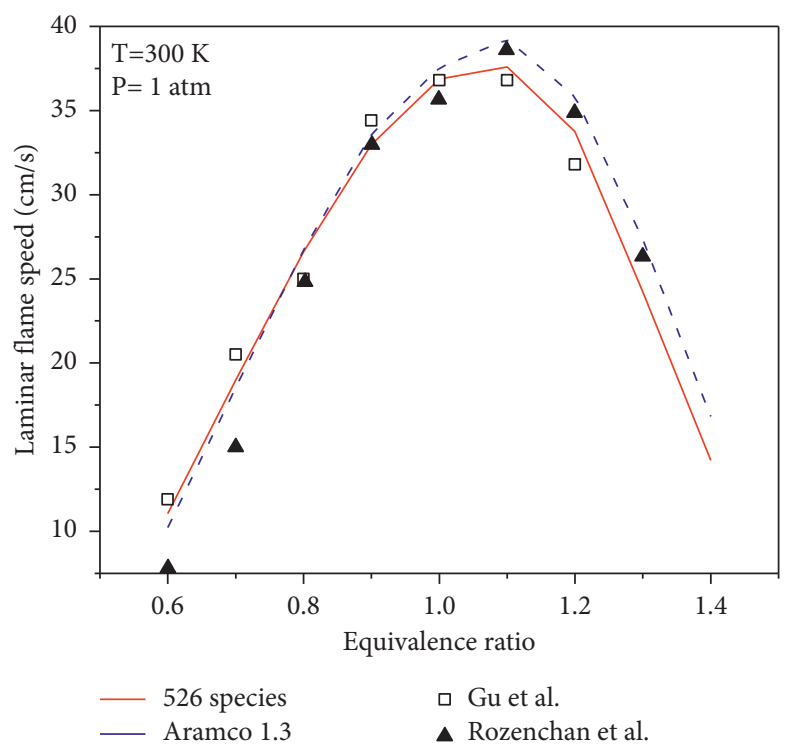

Figure 4: Laminar flame speed validation for methane. The experimental data used for comparison were taken from Gu et al. [53] and Rozenchan et al. [54].

In general, the simplified mechanism is in good agreement with the experimental data for the ignition delay and laminar flame speed of the methane-air mixture. In the next section, the ignition characteristics of methane and $\mathrm{n}$-dodecane dual fuel will be analyzed.

2.3. Numerical Setup. In this paper, the influence of the mixture composition of the dual fuel on ignition delay is analyzed, so the correlation equation is described by the mixture of $\mathrm{n}$-dodecane, methane, and air. Assuming that the molar composition percentages of $\mathrm{N}_{2}$ and $\mathrm{O}_{2}$ in the air are $79 \%$ and $21 \%$, respectively, the stoichiometric equation for hydrocarbon fuel $\mathrm{C}_{x} \mathrm{H}_{y}$ is defined as follows:

$$
\mathrm{C}_{x} \mathrm{H}_{y}+z\left(\mathrm{O}_{2}+3.76 \mathrm{~N}_{2}\right) \longrightarrow x \mathrm{CO}_{2}+\left(\frac{y}{2}\right) \mathrm{H}_{2} \mathrm{O}+3.76 z \mathrm{~N}_{2}
$$

where $z=x+(y / 4)$. follows:

Here, the equivalence ratio of $\phi_{\text {total }}$ and $\phi_{\mathrm{CH}_{4}}$ is defined as

$$
\begin{gathered}
\phi_{\text {total }}=\phi_{\mathrm{CH}_{4}}+\phi_{n-\mathrm{C}_{12} \mathrm{H}_{26}}, \\
\phi_{\mathrm{CH}_{4}}=\frac{X_{\mathrm{CH}_{4}} / X_{\text {Air }}}{\left(X_{\mathrm{CH}_{4}} / X_{\text {Air }}\right)_{\text {stoic }}}, \\
X_{\text {Fuel }}=X_{n-\mathrm{C}_{12} \mathrm{H}_{26}+X_{\mathrm{CH}_{4}}},
\end{gathered}
$$

where $X_{\text {Fuel }}, X_{\text {Air }}, X_{n-\mathrm{C}_{12} \mathrm{H}_{26}}$, and $X_{\mathrm{CH}_{4}}$ represent the fuel mole fractions, the air mole fractions, the $\mathrm{n}$-dodecane mole fractions, and the methane mole fractions, respectively.

Since the dual-fuel combustion process consists of three parts- $n$-dodecane, methane, and air-the sum of the defined mole fraction is unity.

$$
X_{\text {Air }}+X_{n-\mathrm{C}_{12} \mathrm{H}_{26}}+X_{\mathrm{CH}_{4}}=1
$$

\section{Results and Discussion}

3.1. Effects of the Equivalence Ratio of Methane on the Ignition Delay. Based on the chemical dynamic mechanism of the present work, the ignition delay time of methane-ndodecane dual fuel under different mole fractions of n-dodecane mixing was simulated. Kahila et al. [34, 35] used the large eddy simulation to study the ignition characteristics of using $n$-dodecane to ignite the methane/air mixture in dual-fuel engine relevant conditions with the spray condition being corresponded with the engine combustion network (ECN) spray A. In this work, since the homogeneous reactor model in the CHEMKIN package is used, the initial temperature of $\mathrm{n}$-dodecane/methane/air mixture is set to $900 \mathrm{~K}$, and the initial pressure was maintained at 60 bar. The problem type is the constrain volume and solver energy equation. On this basis, the simulation conditions are changed. Figure 5 shows the ignition characteristics of n-dodecane/methane/air mixture at initial temperatures of $900 \mathrm{~K}$ and $1200 \mathrm{~K}$ and an initial pressure of 60 bar. The heat loss is set to $0 \mathrm{~J} / \mathrm{s}$ in the simulation calculation. The ignition problem under different mole fractions of $n$-dodecane at a fixed methane equivalence ratio was studied. Figure 5(a) shows that the ignition delay time first decreases and then increases with the increase of $\mathrm{n}$-dodecane mole fraction when the initial temperature of the methane/air mixture is $900 \mathrm{~K}$. This can be explained by the fact that when the mole fraction of $\mathrm{n}$-dodecane is close to zero, the reaction rate is greatly limited and the ignition is relatively difficult because methane is a low reactivity fuel, resulting in a long ignition delay time. In addition, the oxygen fraction and temperature of the reaction zone will be reduced with the increase of $\mathrm{n}$-dodecane mole fraction because $\mathrm{n}$-dodecane will produce 


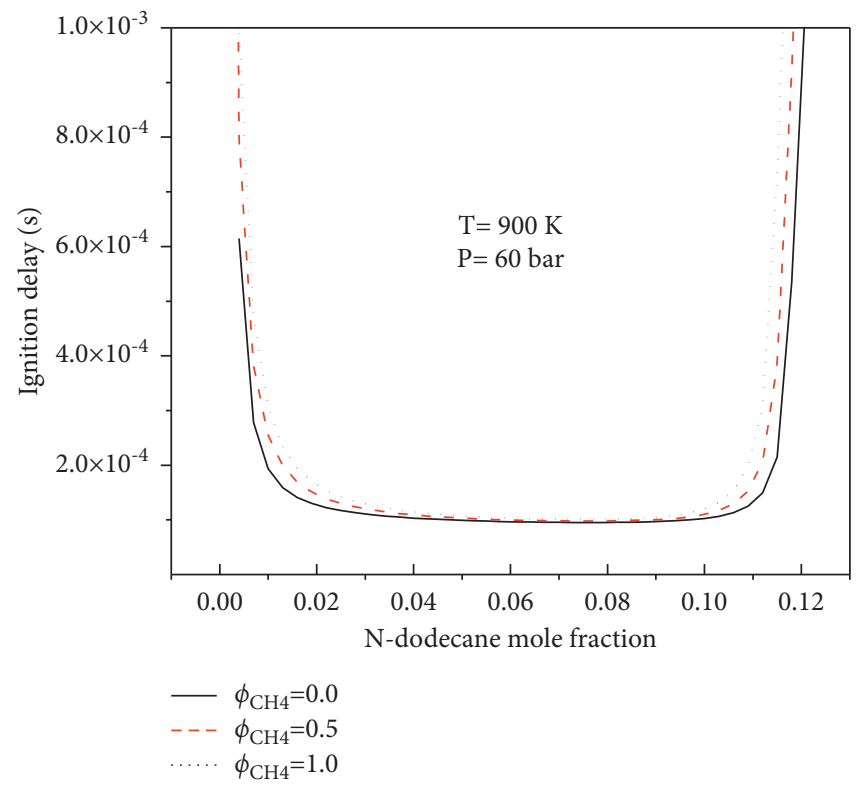

(a)

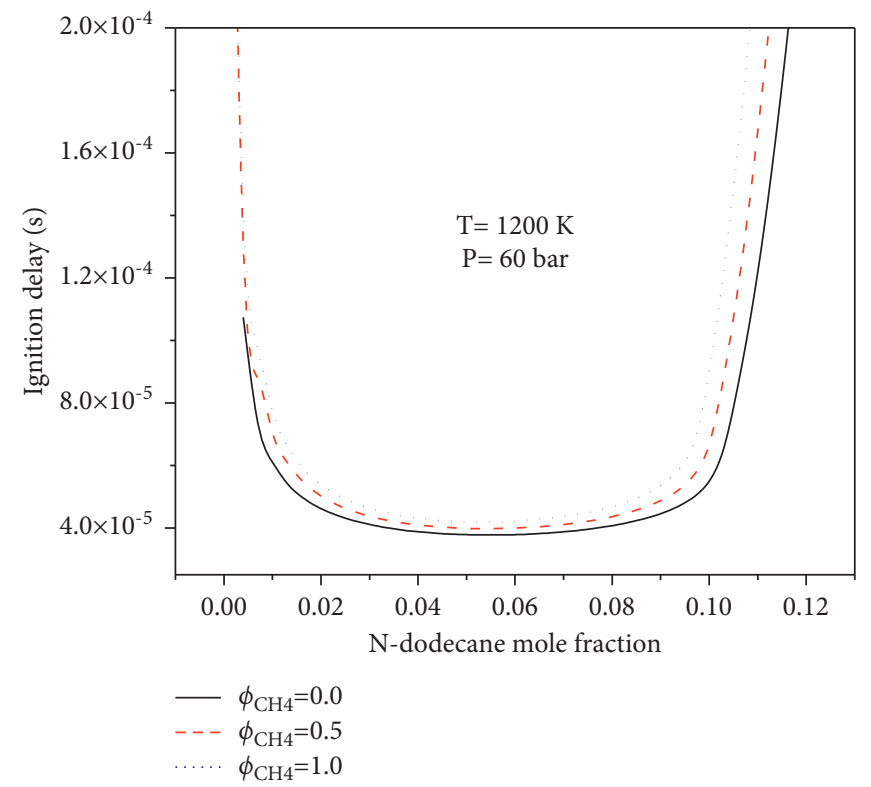

(b)

FIGURE 5: Ignition delay of $\mathrm{n}$-dodecane with different mole fractions at $900 \mathrm{~K}$ and $1200 \mathrm{~K}$ methane-air mixture corresponding to $\phi_{\mathrm{CH}_{4}}=0$, 0.5 , and 1 .

a rich combustion zone and has high vaporization latent heat, and eventually, the ignition delay will increase. Furthermore, the general trend is similar to that at $900 \mathrm{~K}$ when the initial temperature rises to $1200 \mathrm{~K}$.

In the present study, the ignition delay time of methane$\mathrm{n}$-dodecane dual fuel with different $\mathrm{n}$-dodecane mixing ratios was simulated. The mixing ratios of $\mathrm{n}$-dodecane were $0 \%, 1 \%, 4 \%, 10 \%, 20 \%, 50 \%$, and $100 \%$. Figure 6 shows the relationship between ignition delay and n-dodecane blending ratio at a pressure of $60 \mathrm{bar}$, an initial temperature of $700-1200 \mathrm{~K}$, and an equivalence ratio of $0.5-1.5$. It can be seen from Figure 6 that the ignition process of methane-ndodecane dual fuel shows a certain negative temperature coefficient (NTC) behavior at medium and low temperatures. Many studies $[32,56]$ reported that the oxidation of large alkanes is characterized by two-stage ignition and NTC behavior. When the $\mathrm{n}$-dodecane mixing ratio decreases, the ignition delay time increases, and the NTC behavior of the total ignition delay time tends to be flat.

It can be seen from Figure 7 that the ignition delay time of methane-n-dodecane dual fuel changes nonlinearly with the increase of $n$-dodecane mixing ratio and the changing trend is consistent, which decreases with the increase of $\mathrm{n}$-dodecane mixing ratio. When the $\mathrm{n}$-dodecane mixing ratio is low, the influence of $n$-dodecane content on the ignition delay time of methane-n-dodecane dual fuel is more significant, while when the $\mathrm{n}$-dodecane mixing ratio is higher than $50 \%$, the effect of n-dodecane content on the ignition delay time of the dual fuel gradually decreases. This is because with the increase of $\mathrm{n}$-dodecane content in unit time, the number of collisions between n-dodecane and oxygen molecules increases, but the collision trend will gradually flatten, which leads to the influence of $n$-dodecane content on the ignition delay time of the dual fuel tends to be gentle with the increase of $\mathrm{n}$-dodecane mixing ratio. Therefore, with the increase of $n$-dodecane content, the reduction degree of the ignition delay time of the whole reaction system decreases.

It can be seen from Figure 5 that the addition of methane will increase the ignition delay of $\mathrm{n}$-dodecane, and the higher the methane content, the more obvious the increase of ignition delay. This may be due to the thermal effect caused by the high heat capacity of methane and the chemical reaction caused by the addition of methane. Li et al. [57] numerically studied the effect of methane addition on the ignition characteristics of n-heptane. A new species $\mathrm{CH}_{4}^{*}$ with the same thermodynamic data as $\mathrm{CH}_{4}$ was proposed, $\mathrm{CH}_{4}^{*}$ will not take part in any chemical reaction, and only the influence of the thermal effect of this species on the ignition process was considered. When $\mathrm{CH}_{4}^{*}$ replaces $\mathrm{CH}_{4}$, the influence of the $\mathrm{CH}_{4}$ chemical reaction will be eliminated, so $\mathrm{CH}_{4}^{*}$ can be used to analyze the influence of the thermal effect. Figure 8 shows different effects of methane addition on the ignition delay time of stoichiometric combustion of n-dodecane and oxygen at an initial temperature of $700-1200 \mathrm{~K}$ and pressures of 20 bar and 60 bar. It can be found that the influence of the methane thermal effect is the most significant in the region of NTC behavior, but it is significantly lower than that of the chemical reaction. Compared with Figures 8(a) and 8(b), it can also be seen that the ignition delay decreases with the increase of the pressure.

In order to distinguish the effects of thermal effect and chemical reaction, the evolution of $\mathrm{OH}$ radicals and temperature with an initial temperature of $900 \mathrm{~K}$ was selected. The ignition delay time defined here was the maximum mole fraction point of $\mathrm{OH}$ radical. From Figure 9, when methane 


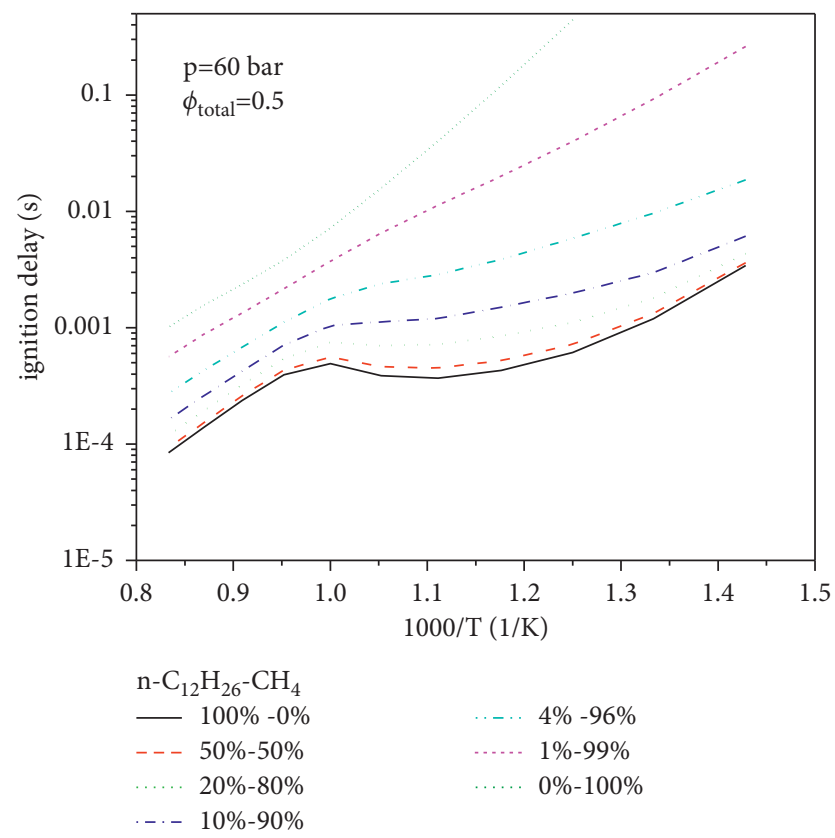

(a)

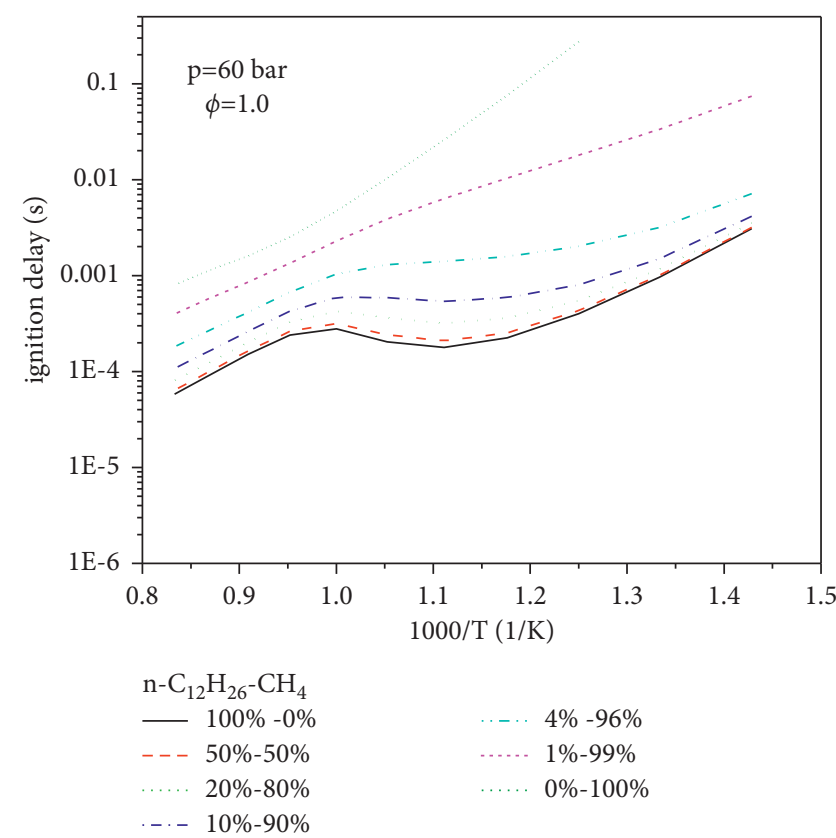

(b)

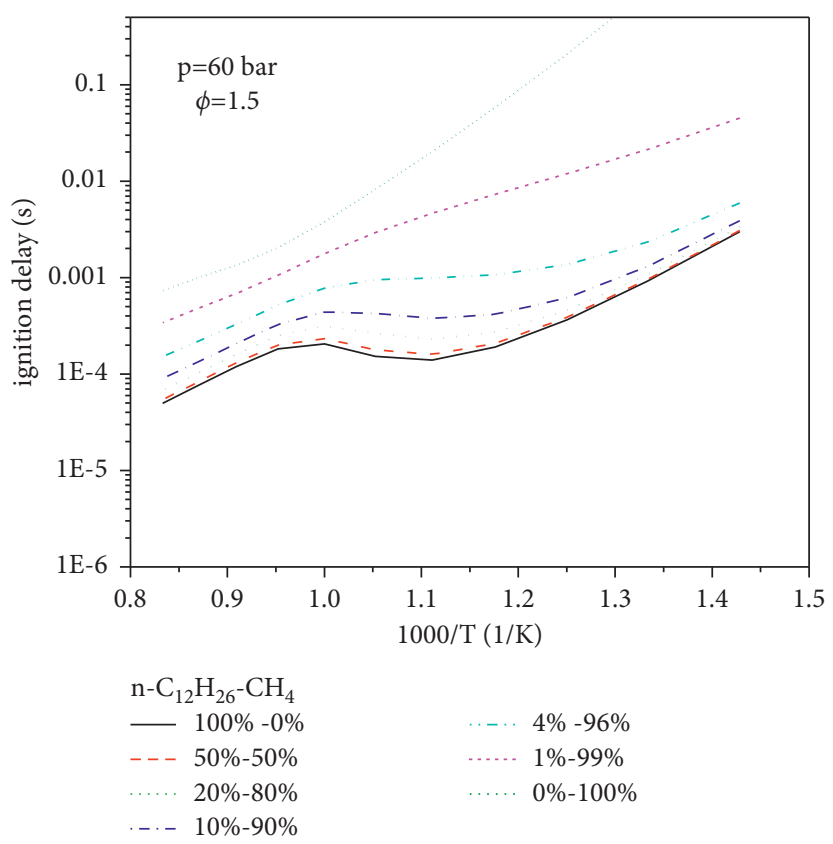

(c)

Figure 6: Ignition delay of different $\mathrm{n}$-dodecane mixing ratios.

is stoichiometric with oxygen, the ignition delay of $\mathrm{n}$-dodecane is $58.51 \%$ at the initial pressure of $20 \mathrm{bar}$, of which $51.48 \%$ is caused by the chemical reaction of methane and $7.03 \%$ by the thermal effect of methane. When the initial pressure is 60 bar, the ignition delay of n-dodecane is $52.63 \%$, of which $43.08 \%$ is caused by the chemical reaction of methane and $9.55 \%$ is caused by the thermal effect of methane. With the increase of pressure, the thermal effect of methane also increases.

The results show that the thermal effect of methane is the most obvious in the middle-temperature region and the chemical reaction of methane plays a key role in the ignition delay in the low- and high-temperature regions. In order to explain the effect of methane chemical reaction on the ignition delay of $n$-dodecane, the reaction path analysis, the rate of production analysis, and the sensitivity analysis will be carried out.

3.2. Evolution of Species. In order to determine the species rate control in the ignition process of the high-reactivity fuel n-dodecane and the low-reactivity fuel methane, the 


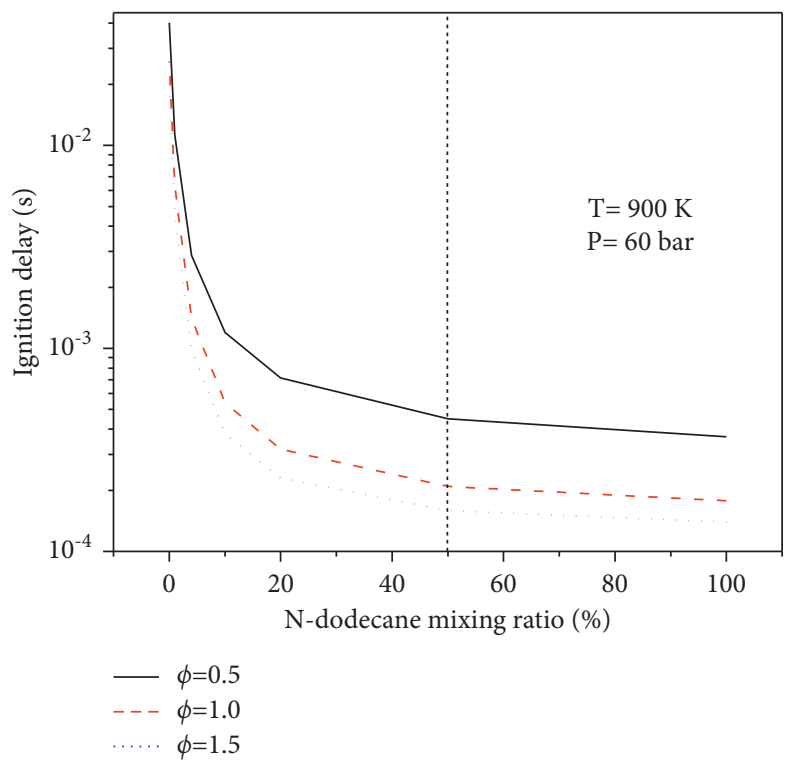

FIgURE 7: Ignition delay of different $\mathrm{n}$-dodecane mixing ratios at an initial temperature of $900 \mathrm{~K}$ and $\phi_{\text {total }}=0.5,1$, and 1.5 .

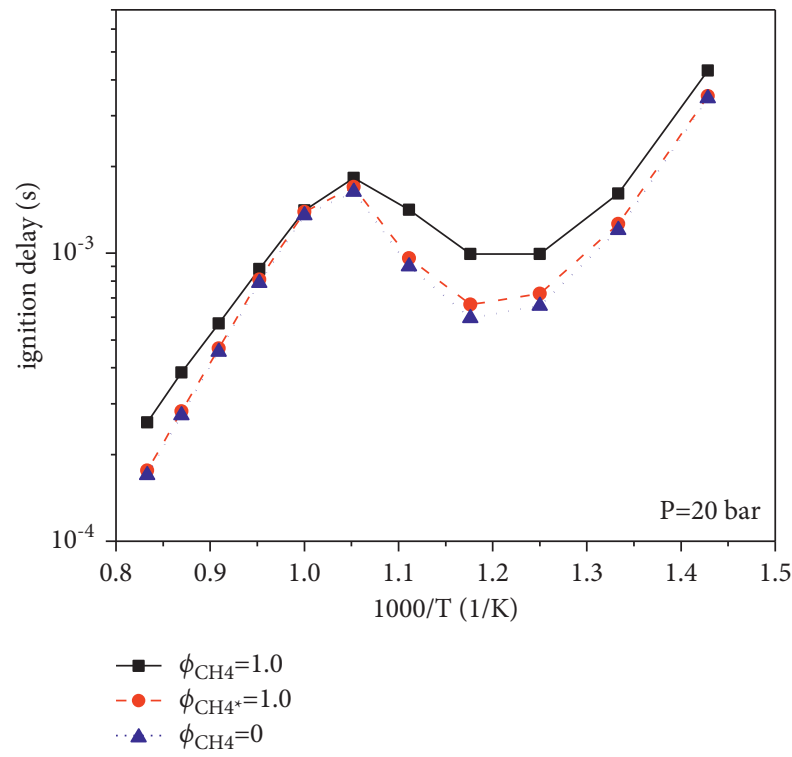

(a)

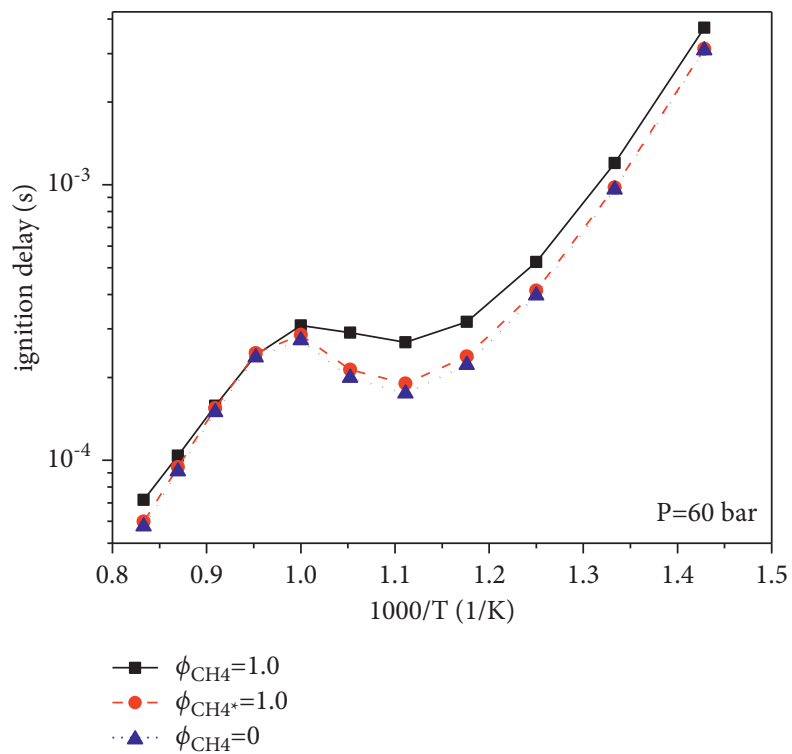

(b)

Figure 8: Different effects of methane addition on ignition delay time.

chemical kinetics of methane-n-dodecane dual fuel was analyzed. Besides, the consumption of the dual fuel and the change of free radical concentration during ignition were investigated.

Figure 10 shows the change curve of free radical mole concentration and temperature for 50\% methane and 50\% n-dodecane dual fuel obtained by simulation under the initial conditions of $P=20$ bar and $\phi_{\text {total }}=1.0$. In addition, three initial temperatures including $700 \mathrm{~K}, 900 \mathrm{~K}$, and $1100 \mathrm{~K}$ were compared. The ignition process of methane-ndodecane dual fuel can be divided into two stages (also called the two-stage ignition process), and the second stage ignition is the total ignition process. Figure 10 shows that methanen-dodecane mainly shows two stages of heat release at initial temperatures $700 \mathrm{~K}$ and $900 \mathrm{~K}$ : low-temperature heat release (LTHR) and high-temperature heat release (HTHR). Most of the free radical accumulation of methane-n-dodecane is completed in the LTHR stage until the HTHR stage. Besides, increasing the mixture's initial temperature can reduce the dual-fuel ignition delay time, and n-dodecane is decomposed faster than methane. Moreover, the accumulation of $\mathrm{HO}_{2}$ and $\mathrm{CH}_{2} \mathrm{O}$ mainly occurred in the LTHR and the accumulation of $\mathrm{H}_{2} \mathrm{O}_{2}$ reaches the peak in the HTHR stage. $\mathrm{N}$-dodecane first decomposes to produce a large number of 


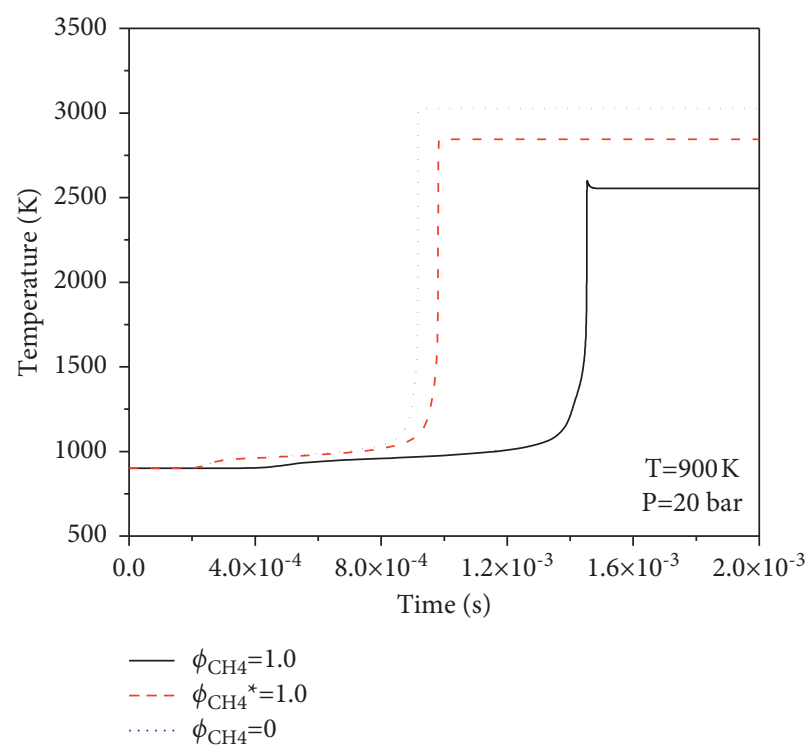

(a)

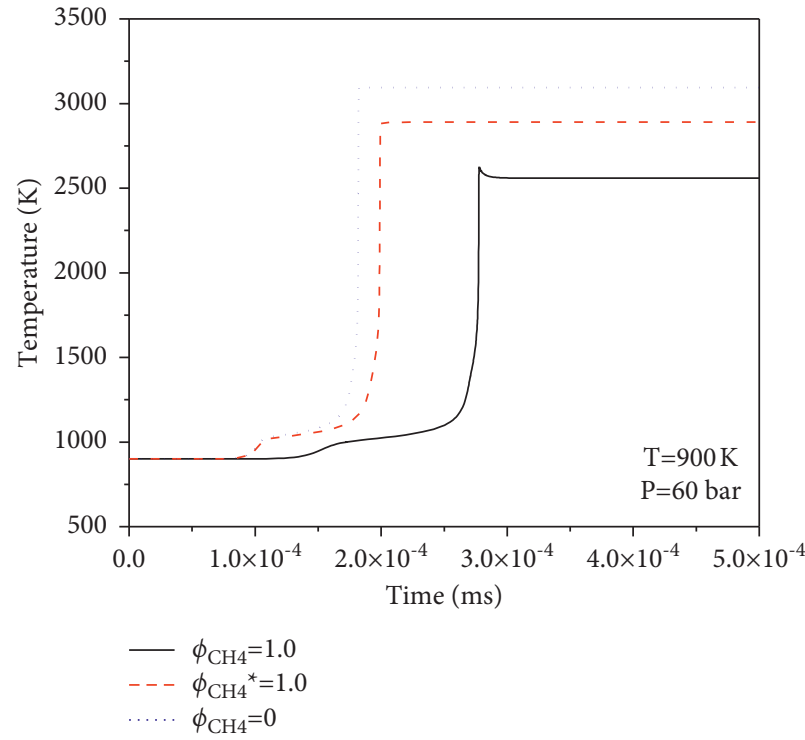

(c)

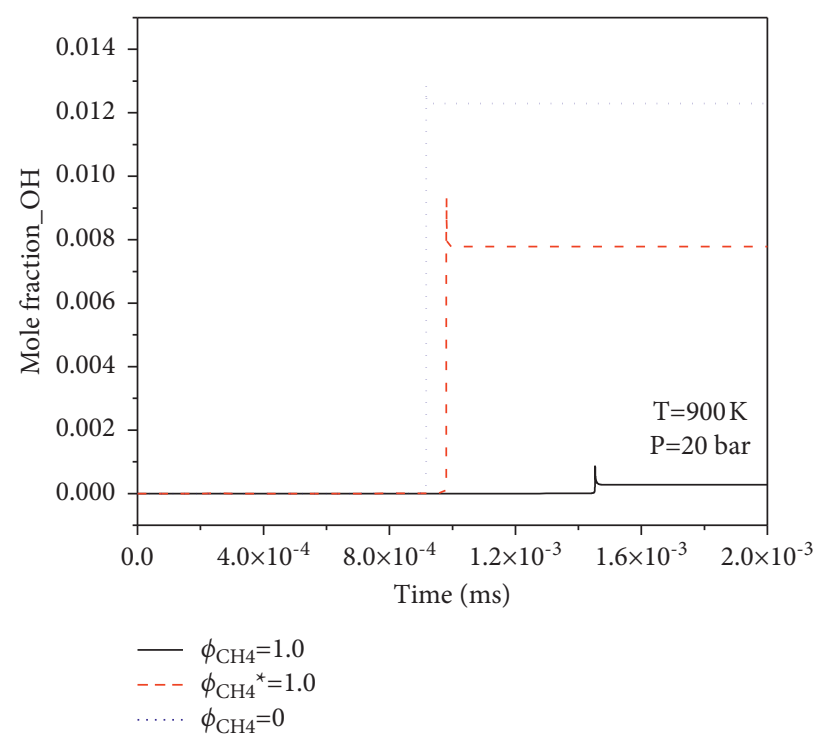

(b)

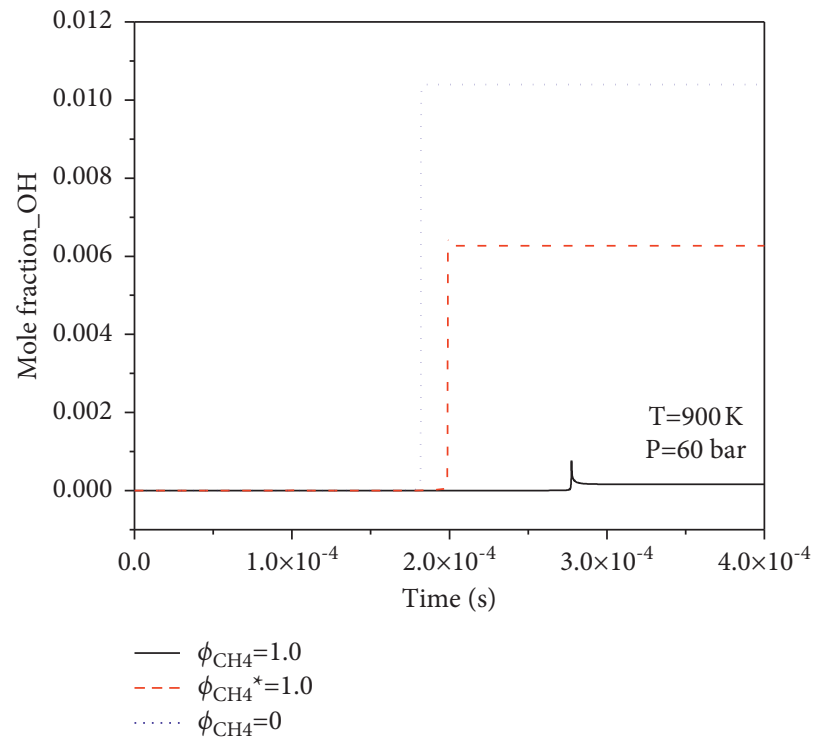

(d)

FIgURE 9: Effect of different methane equivalence ratios on the evolution of temperature and $\mathrm{OH}$ radicals.

free radicals. Compared with $\mathrm{n}$-dodecane, methane cannot provide enough heating and free radical pool accumulation during LTHR. This can be due to the weak bond of $\mathrm{n}$-dodecane molecules, which leads to faster decomposition. This explains that $\mathrm{n}$-dodecane can be used as a pilot oil to ignite methane. As shown in Figure 10(c), with the increase of the mixture's initial temperature, the heat release process of methane and n-dodecane changes from LTHR and HTHR to single-stage HTHR. When the initial temperature reaches $1100 \mathrm{~K}$, the mole fraction of methane increases because $\mathrm{n}$-dodecane is rapidly decomposed into methane with the increase of initial temperature, increasing methane mole fraction. Methane and n-dodecane are completely consumed at the same time. Furthermore, n-dodecane decomposes faster than methane.
Figure 11 shows the simulated curves of free radical concentration and temperature of methane-n-dodecane dual fuel with different mixing ratios at $P=20 \mathrm{bar}$, $\phi_{\text {total }}=1.0$, and $T=700 \mathrm{~K}$. It can be seen that the ignition delay time decreases with the increase of $n$-dodecane mixing ratio, which is a good explanation for the previous section. With the increase of the n-dodecane mixing ratio, the time for methane to be consumed completely is decreased, which indicates that $\mathrm{n}$-dodecane promotes methane consumption to a certain extent. Besides, the conversion rate of $\mathrm{n}$-dodecane slows down with the increase of the methane mixing ratio, and the higher the methane mixing ratio, the more obvious this effect. This may be related to the chemical reaction caused by methane, which will be analyzed in the next section. Moreover, the heat release process of methane 


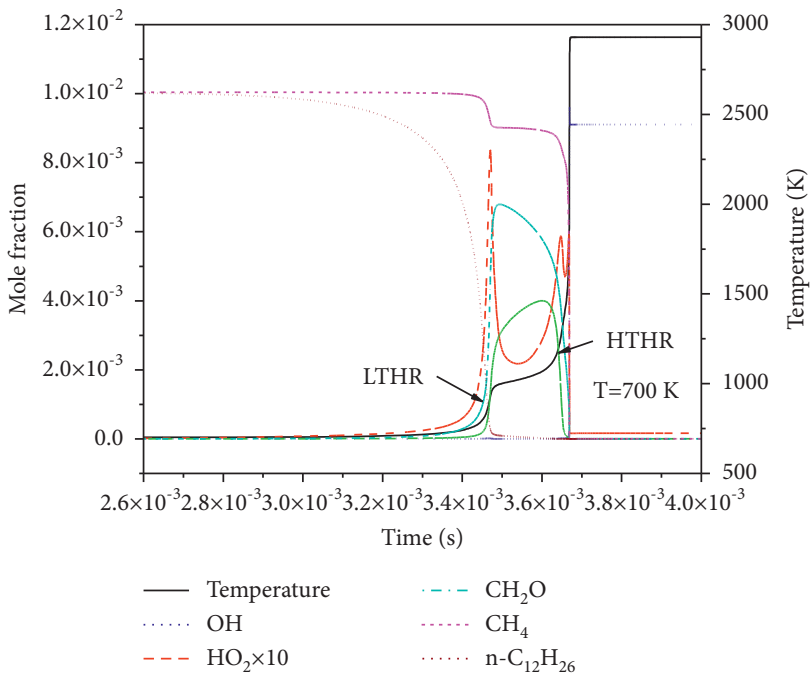

(a)

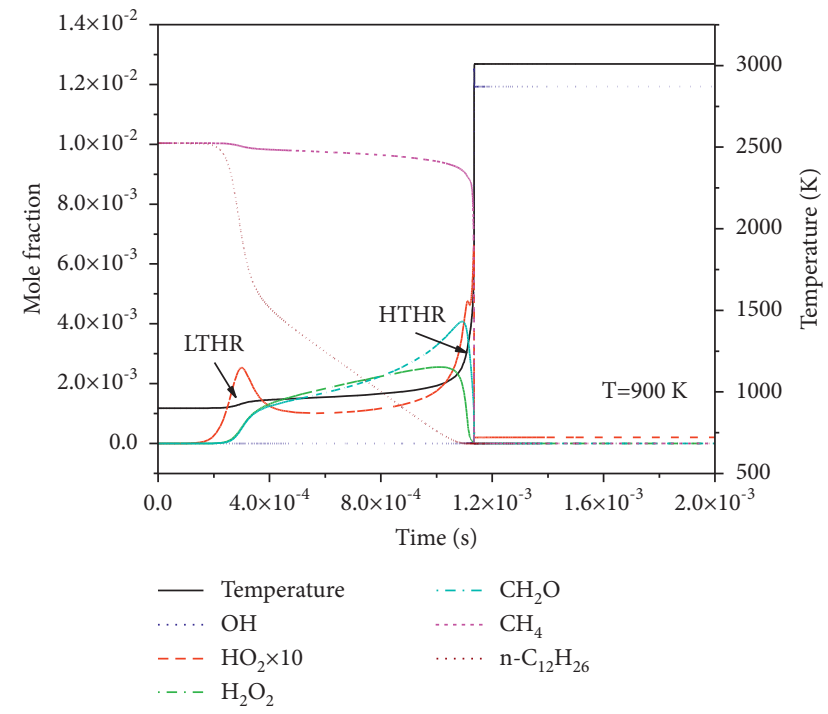

(b)

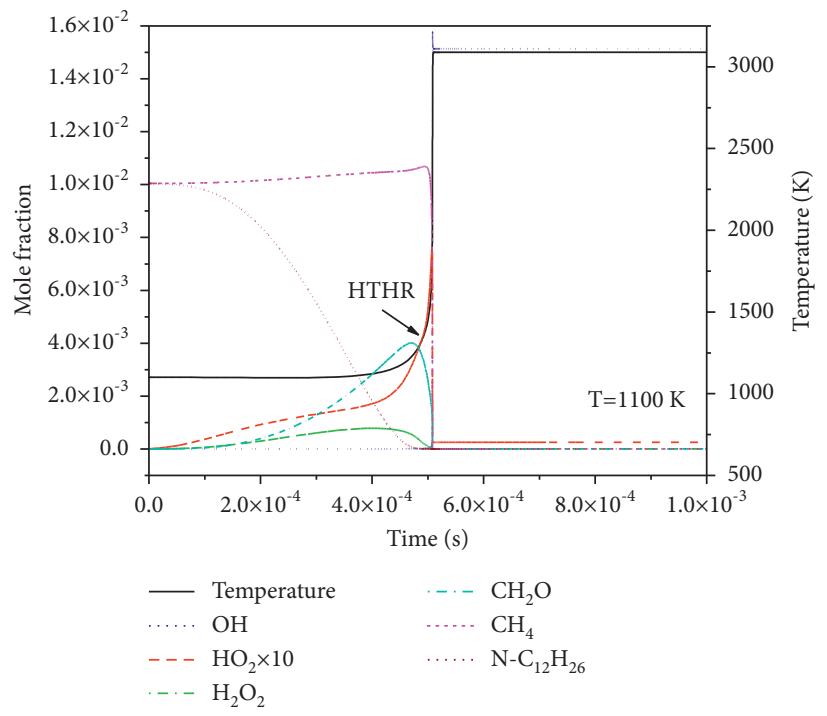

(c)

Figure 10: Species evolution of methane-n-dodecane mixtures at different initial temperatures at $\phi_{\text {total }}=1.0, P=20$ bar.

and n-dodecane changes from LTHR and HTHR to singlestage HTHR with the increase of the $\mathrm{n}$-dodecane mixing ratio. When the concentration of free radicals accumulates enough, the second stage of ignition occurs. At the first stage of ignition, the concentration of $\mathrm{n}$-dodecane decreases rapidly, which indicates that a large amount of $\mathrm{n}$-dodecane is consumed during the first stage of ignition. After the first stage of ignition, the consumption rate of $\mathrm{n}$-dodecane begins to decrease and then the concentration of methane decreases rapidly during the second stage of ignition. Finally, methane and $\mathrm{n}$-dodecane are consumed completely during the second stage of ignition.

It can be seen from Figures 10 and 11 that the contents of methane and $\mathrm{n}$-dodecane change after the initial level is maintained for a period of time. Comparing the LTHR under these conditions, it can be said that the time when the content of methane and $\mathrm{n}$-dodecane is maintained at the initial level is just equal to the ignition process of the first stage. Before the first stage of ignition, the concentration of fuel in the whole reaction system changes a little. At this time, the dual-fuel is in the preparation stage and some severe chemical reactions begin to appear in the reaction system until the first stage of ignition.

3.3. Analysis of the Dominant Reactions and Reaction Pathways Affecting the Ignition. According to the consumption trend of methane-n-dodecane dual fuel in the previous section, the reaction rate and the reaction pathway of the main consumption reaction elements of the dual-fuel during the ignition process were determined. As shown in Figure 12 , n-dodecane undergoes dehydrogenation, 


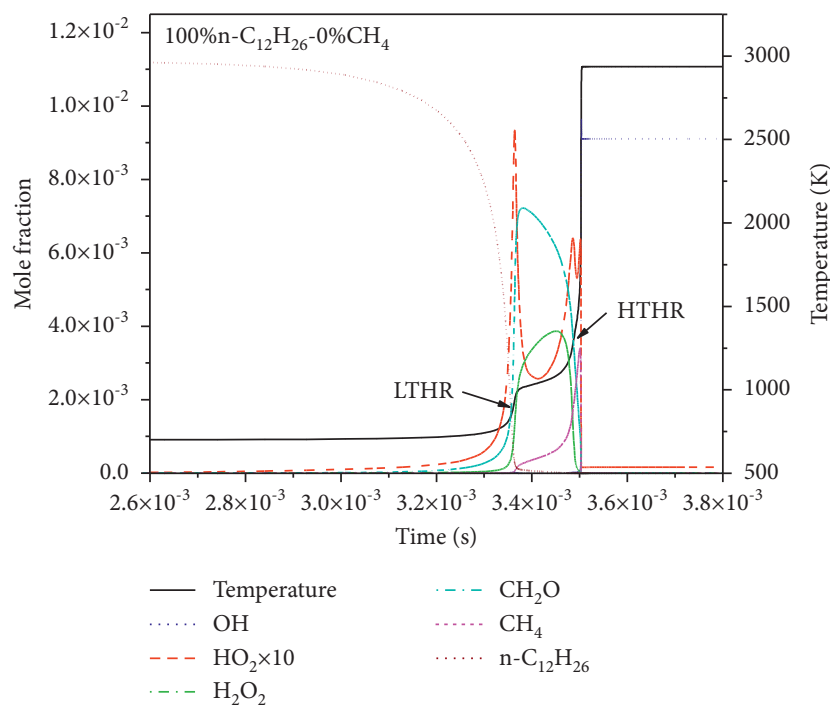

(a)

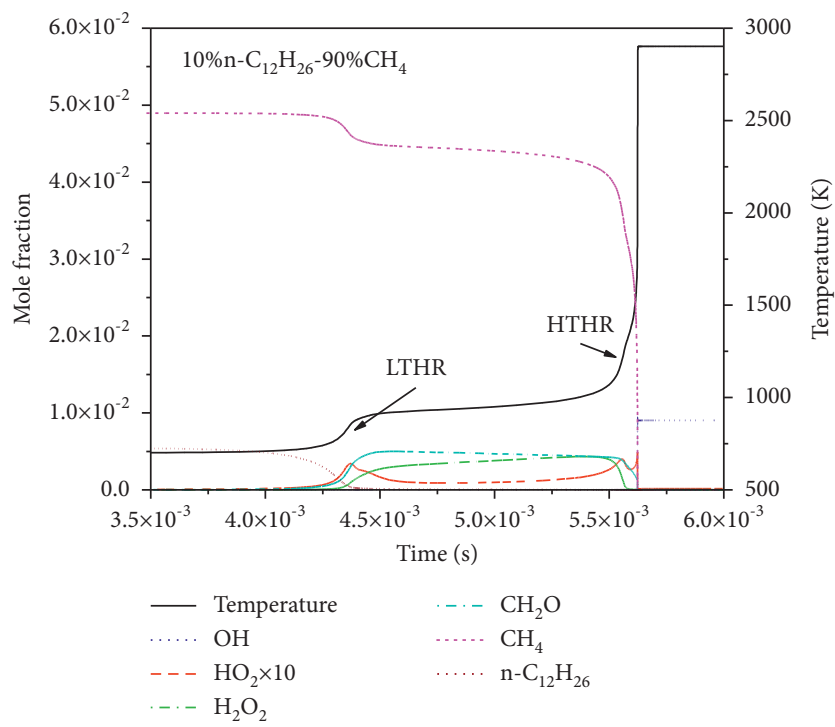

(c)

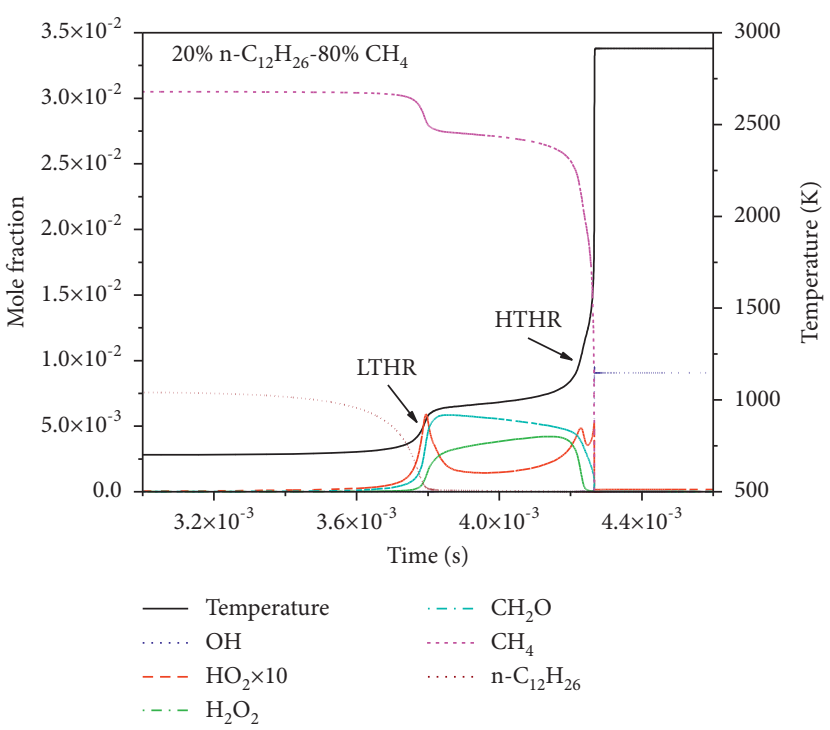

(b)

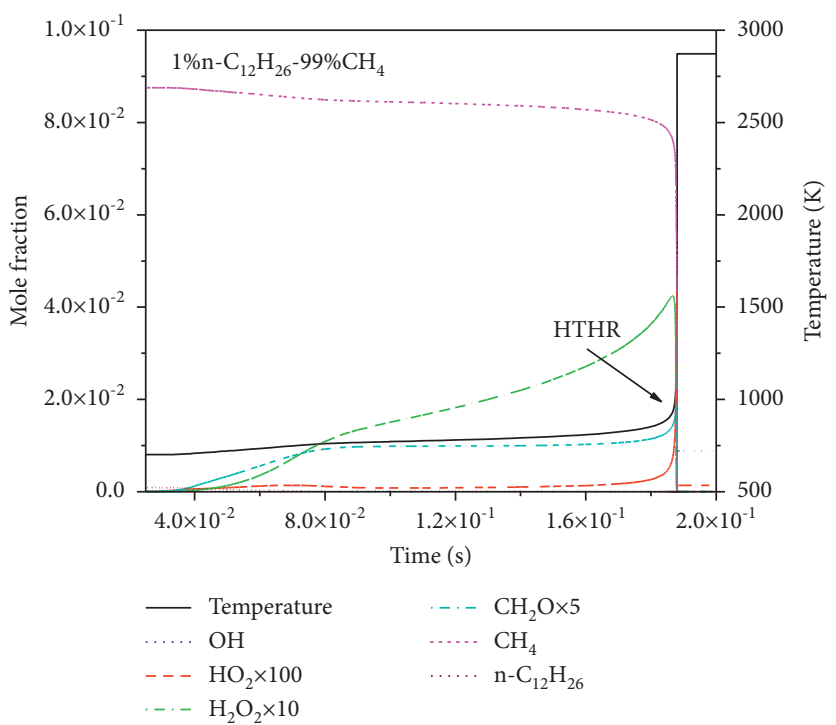

(d)

FIgURE 11: Species evolution of different methane-n-dodecane mixing ratios at $\phi_{\text {total }}=1.0, P=20$ bar, and $T=700 \mathrm{~K}$.

isomerization, twice oxidation, and so on to produce a variety of isomers, where $\mathrm{R}$ represents $\mathrm{C}_{12} \mathrm{H}_{25}$-n radicals, Q represents $\mathrm{C}_{12} \mathrm{H}_{24}-\mathrm{n}$ radicals, and KET represents ketohydroperoxide. Figure 12 shows that different methane conversion rate reaction pathways of 50\% methane and 50\% n-dodecane dual-fuel oxidation at initial $T=900 \mathrm{~K}$ and $P=60 \mathrm{bar}$. The methane conversion rate at this point is defined as molar conversion, which is the percentage of the number of molar units consumed.

At the initial stage of the reaction, methane consumption is very small. The ignition process of $\mathrm{n}$-dodecane dominates the transition from low-temperature reaction to high-temperature reaction. As shown in Figure 12(a), the decomposition of $n$-dodecane first occurs in the reaction $n-\mathrm{C}_{12} \mathrm{H}_{26}+$ $\mathrm{O}_{2}=\mathrm{R}+\mathrm{HO}_{2}$ to form $\mathrm{R}$. Since there are many isomers, all the following elementary reactions are replaced by symbols. According to the reaction pathway of $\mathrm{n}$-dodecane, the oxidation of $\mathrm{R}$ is mainly through $\mathrm{R}+\mathrm{O}_{2}=\mathrm{RO}_{2}$. Because $\mathrm{R}+\mathrm{O}_{2}=\mathrm{RO}_{2}$ is a dominant reaction at low temperatures, it produces $\mathrm{RO}_{2}$, which leads to the reaction of $\mathrm{RO}_{2}=\mathrm{QOOH}$, $\mathrm{QOOH}+\mathrm{O}_{2}=\mathrm{O}_{2} \mathrm{QOOH}, \quad \mathrm{O}_{2} \mathrm{QOOH}=\mathrm{C}_{12} \mathrm{KET}+\mathrm{OH}$, and $\mathrm{C}_{12} \mathrm{KET}=\mathrm{OH}+$ Oxygenated. In the above reaction, the $\mathrm{OH}$ produced by $\mathrm{C}_{12} \mathrm{KET}=\mathrm{OH}+$ Oxygenated reacts with n-dodecane and methane: $\mathrm{n}-\mathrm{C}_{12} \mathrm{H}_{26}+\mathrm{OH}=\mathrm{R}+\mathrm{H}_{2} \mathrm{O}$, and then $\mathrm{R}$ contributes to $\mathrm{R}+\mathrm{O}_{2}=\mathrm{RO}_{2}, \mathrm{CH}_{4}+\mathrm{OH}=\mathrm{CH}_{3}+\mathrm{H}_{2} \mathrm{O}$. Methane consumes $\mathrm{OH}$ radicals, inhibits the oxidation path of $\mathrm{n}$-dodecane at low temperatures and increases reaction time. When the conversion of methane is $10 \%$, as shown in Figure 12(b), many intermediate products (aldehydes, ketones, etc.) and important free radicals $\left(\mathrm{OH}, \mathrm{HO}_{2}\right.$, etc.) will be 


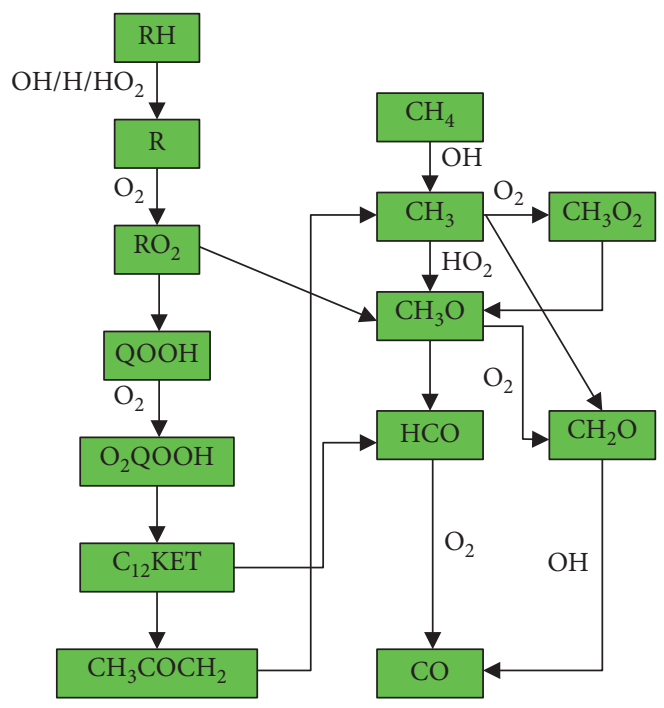

(a)

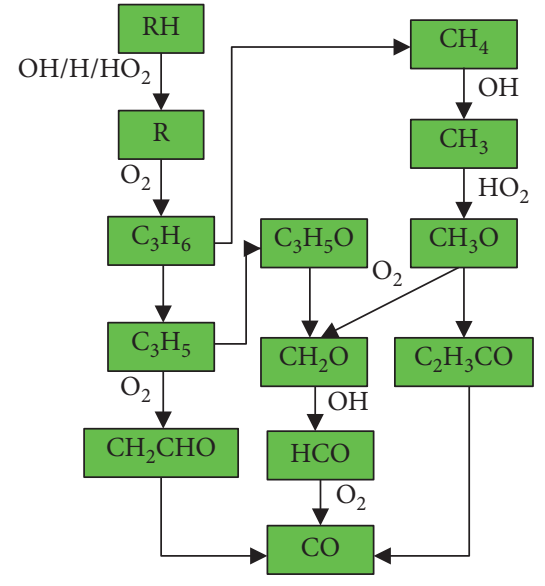

(b)

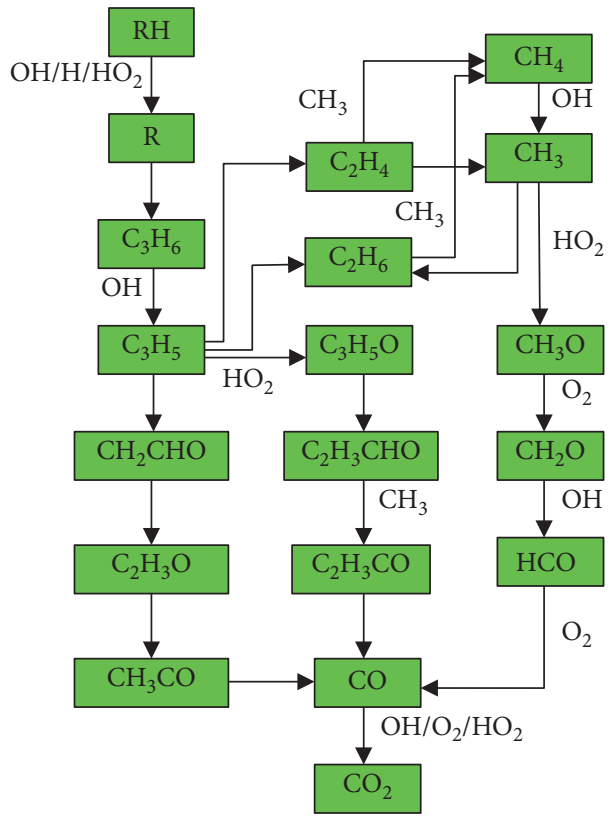

(c)

FIGURE 12: Reaction pathway of different methane conversion rates: (a) $1 \%$ methane conversion rate, (b) $10 \%$ methane conversion rate, and (c) $50 \%$ methane conversion rate.

produced in this process, which provides a good initial condition for the subsequent reaction. When the conversion of methane is $50 \%$, it can be seen from Figure 12(c) that the addition of methane seems to promote the reaction of $\mathrm{n}$-dodecane and make up for the negative effect of $\mathrm{OH}$ radical consumption, so the effect of methane is very small at this time. In summary, the effect of methane on the ignition delay of $\mathrm{n}$-dodecane is mainly in the early stage of oxidation process, which will increase the ignition delay time of n-dodecane.

Through the above analysis, the role of $\mathrm{OH}$ radicals in chemical kinetics and the main reason for the short ignition delay time of $\mathrm{n}$-dodecane combustion are explained. In this study, the ignition delay sensitivity of the simplified mechanism of 526 species was analyzed to further evaluate the oxidation process.

In order to explain the influence of different mixing ratios of methane and n-dodecane on the ignition process in this study, five typical mixing ratios were analyzed and the reaction sensitivity analysis was carried out for the important reactions at 60 bar. The sensitivity coefficient $S_{i}$ is defined as follows:

$$
S_{i}=\frac{\tau\left(2 k_{i}\right)-\tau\left(0.5 k_{i}\right)}{1.5 \tau\left(k_{i}\right)},
$$

where $S_{i}$ is the sensitivity coefficient of ignition delay time, $\tau$ is ignition delay time, and $k_{i}$ is the rate of the $i^{\text {th }}$ reaction. A negative $S_{i}$ indicates that the reaction can promote the 

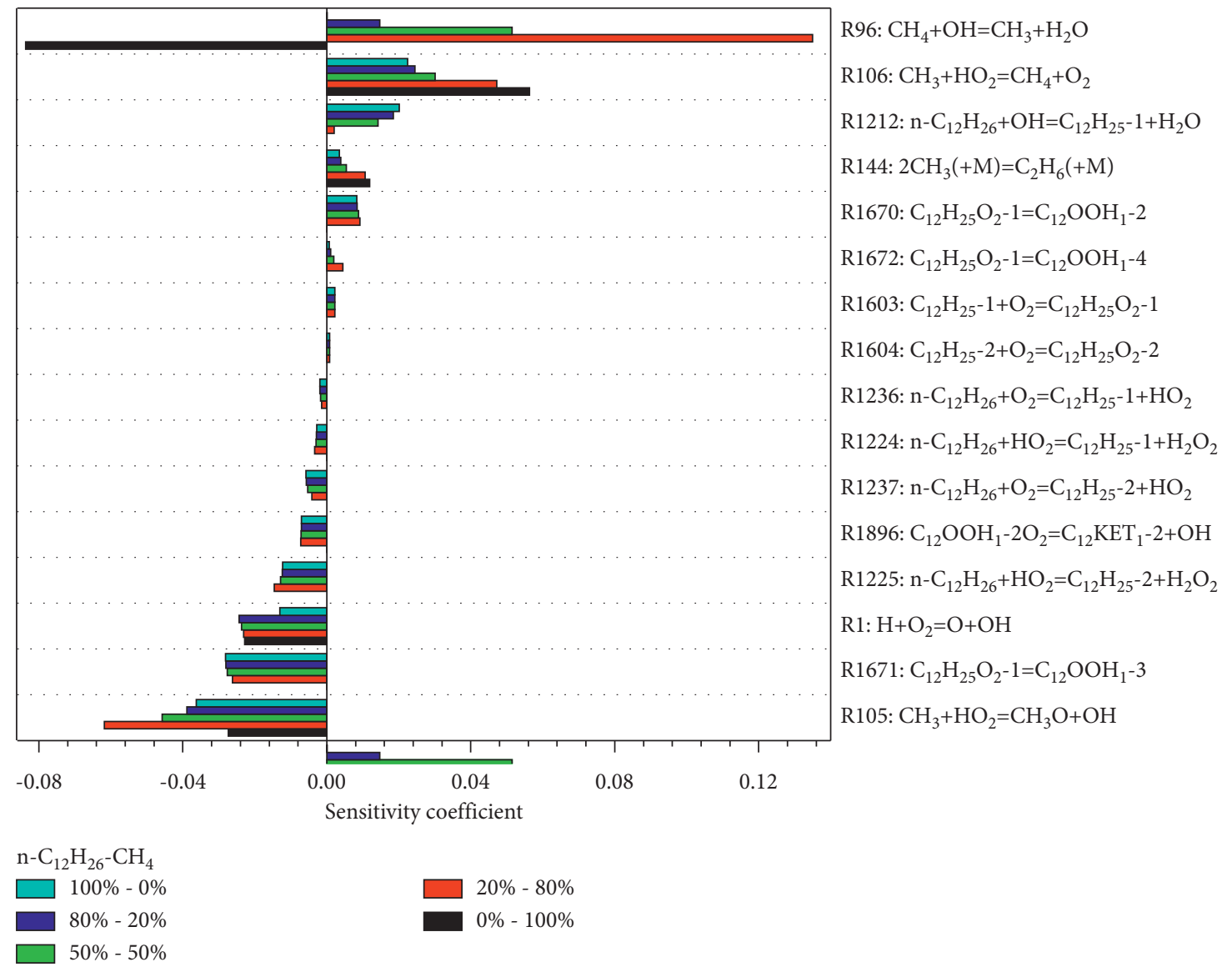

FIGURE 13: Sensitivity coefficient of ignition delay time for key reactions of methane-n-dodecane at $T=900 \mathrm{~K}, P=20 \mathrm{bar}$, and $\phi_{\text {total }}=1.0$.

ignition of the fuel, whereas a positive $S_{i}$ indicates that the reaction inhibited the ignition of the fuel.

Figure 13 shows the normalized sensitivity coefficient of ignition delay time with various methane-n-dodecane mixtures. It is obvious that for pure methane fuel $\left(\mathrm{n}-\mathrm{C}_{12} \mathrm{H}_{26^{-}}\right.$ $\mathrm{CH}_{4}: 0 \%-100 \%$ ), the reaction sensitivity coefficient of related species of $\mathrm{n}$-dodecane is 0 because there are no related species of $\mathrm{n}$-dodecane involved in the reaction. The reactions $\mathrm{R} 1\left(\mathrm{H}+\mathrm{O}_{2}=\mathrm{O}+\mathrm{OH}\right)$ and $\mathrm{R} 96\left(\mathrm{CH}_{4}+\mathrm{OH}=\mathrm{CH}_{3}+\mathrm{H}_{2} \mathrm{O}\right)$ have a high negative sensitivity coefficient. For R105 $\left(\mathrm{CH}_{3}+\mathrm{HO}_{2}=\mathrm{CH}_{3} \mathrm{O}+\mathrm{OH}\right)$, a low-reactive methyl radical is consumed to form a high-reactive $\mathrm{OH}$ radical, so it also has a negative sensitivity coefficient. However, for the reaction of methyl, R144 $\left(2 \mathrm{CH}_{3}(+\mathrm{M})=\mathrm{C}_{2} \mathrm{H}_{6}(+\mathrm{M})\right)$ consumes the methyl radical and $\mathrm{R} 106\left(\mathrm{CH}_{3}+\mathrm{HO}_{2}=\mathrm{CH}_{4}+\mathrm{O}_{2}\right)$ consumes methyl to form $\mathrm{CH}_{4}$, which inhibits the ignition process, so it has a high positive sensitivity coefficient. For pure dodecane fuel (n- $\mathrm{C}_{12} \mathrm{H}_{26}-\mathrm{CH}_{4}$ : $\left.100 \%-0 \%\right)$, $\mathrm{R} 1212$ (n$\mathrm{C}_{12} \mathrm{H}_{26}+\mathrm{OH}=\mathrm{C}_{12} \mathrm{H}_{25}-1+\mathrm{H}_{2} \mathrm{O}$ ) reactions consume the highly active $\mathrm{OH}$ radical and inhibit the ignition process, and therefore, they have a high positive sensitivity coefficient.

According to the sensitivity coefficients of different mixing ratios of methane and n-dodecane in Figure 13, it can be seen that R96 dominates with the increase of methane mixing ratio and inhibits the ignition process. Although $\mathrm{R} 1225\left(\mathrm{n}-\mathrm{C}_{12} \mathrm{H}_{26}+\mathrm{HO}_{2}=\mathrm{C}_{12} \mathrm{H}_{25}-2+\mathrm{H}_{2} \mathrm{O}_{2}\right)$ can promote the ignition process in the presence of methane, R96 can inhibit the ignition process more obviously in the case of a higher methane mixing ratio. However, this type of reaction has a less significant inhibitory effect at a lower methane mixing ratio. For example, in Figure 7 , when the methane mixing ratio is less than $50 \%$, the effect is not so obvious. In addition, in all the reactions of methane with methyl, the sensitivity coefficient of all the reactions decreases obviously with the increase of the $n$-dodecane mixing ratio, which weakens the influence of methane on the ignition process.

In the ignition process of methane-n-dodecane mixture, free radicals such as $\mathrm{H}$ and $\mathrm{OH}$ play a very important role in the ignition process. Almost all the elementary reactions are initiated, propagated, and terminated by free radicals. In this section, the influence of the mixture ratio of $n$-dodecane on the reaction rate of production (ROP) of free radicals was studied. The rate of production and consumption of $\mathrm{H}$ and $\mathrm{OH}$ free radicals are shown in Figure 14 under the conditions of $\phi_{\text {total }}=1.0, T=900 \mathrm{~K}$, and $P=60$ bar.

Figure 14(a) shows the production and consumption of $\mathrm{H}$ radicals. From Figure 14(a), the main reactions are R1, R2 $\left(\mathrm{O}+\mathrm{H}_{2}=\mathrm{H}+\mathrm{OH}\right), \quad \mathrm{R} 3 \quad\left(\mathrm{OH}+\mathrm{H}_{2}=\mathrm{H}+\mathrm{H}_{2} \mathrm{O}\right), \quad \mathrm{R} 24$ $\left(\mathrm{CO}+\mathrm{OH}=\mathrm{CO}_{2}+\mathrm{H}\right)$, and $\mathrm{R} 26(\mathrm{HCO}+\mathrm{M}=\mathrm{H}+\mathrm{CO}+\mathrm{M})$. The reaction $\mathrm{R} 1$ consumes $\mathrm{H}$ radicals. Besides, the reaction rates of R2, R3, R24, and R26 increase with the decrease of methane mixing ratio, and more $\mathrm{H}$ radicals are produced, which promotes the reaction of $\mathrm{R} 1$. It can be seen that the 


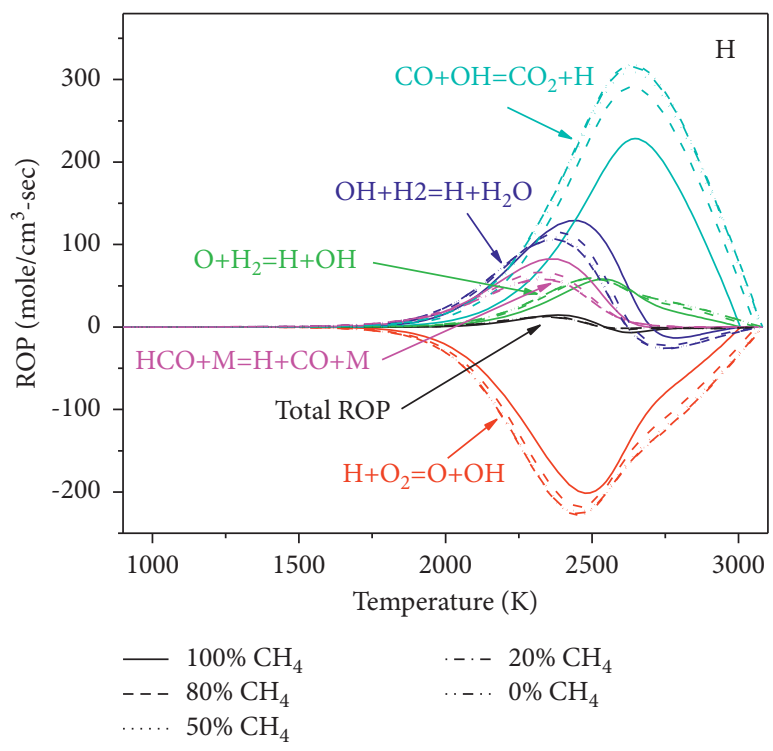

(a)

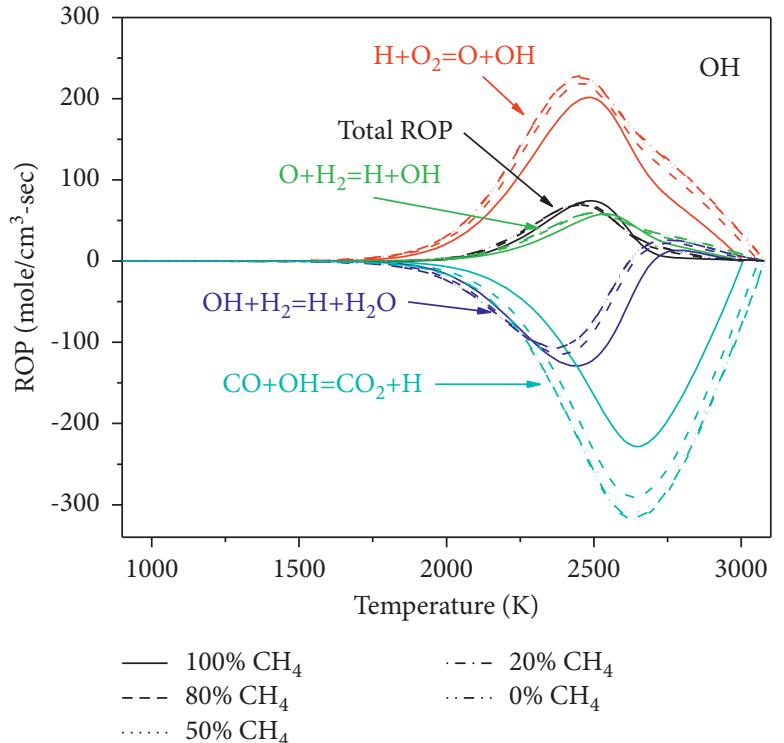

(b)

Figure 14: Rates of production and consumption for $\mathrm{H}$ and $\mathrm{OH}$ radicals under different methane-n-dodecane mixing ratios.

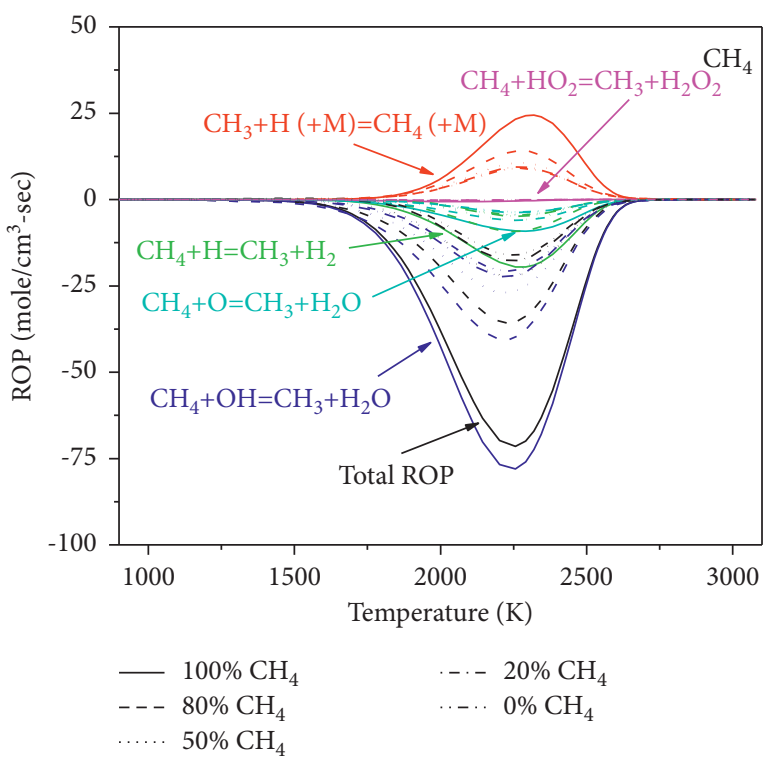

(a)

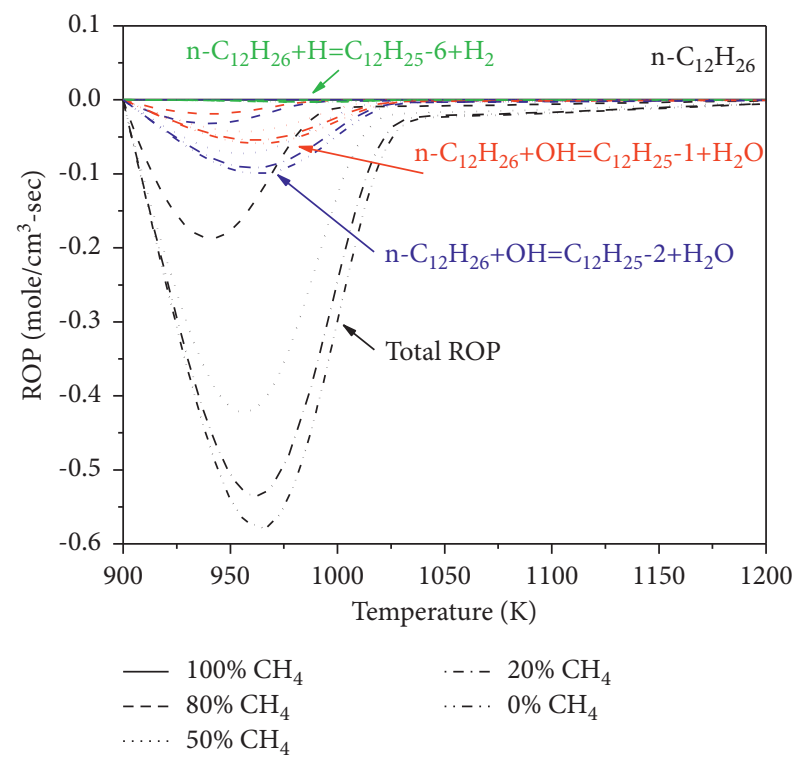

(b)

FIgURE 15: Rates of production and consumption for $\mathrm{CH}_{4}$ and $n-\mathrm{C}_{12} \mathrm{H}_{26}$ radical through the key reactions with various methane-ndodecane mixing ratios.

reaction that plays a leading role in the formation of $\mathrm{H}$ radicals gradually turns from R3 to R24, which will be the main path for the formation of $\mathrm{H}$ radicals. Compared with $\mathrm{R} 2$ and R3, the reaction rate of R24 is greatly increased, resulting in the increase of $\mathrm{H}$ radical concentration and the acceleration of chain branching with the increase of the $\mathrm{n}$-dodecane mixing ratio.

As can be seen from Figure 14(b), R1 and R2 are the main reactions to produce $\mathrm{OH}$ radicals, while $\mathrm{R} 3$ and $\mathrm{R} 24$ are the main reactions to consume $\mathrm{OH}$ radicals. With the decrease of methane mixing ratio, the reaction rates of $\mathrm{R} 1$ and $\mathrm{R} 2$ to generate $\mathrm{OH}$ radicals increase, which leads to the increase of $\mathrm{OH}$ concentration and promotes the total reaction rate. In conclusion, the reaction rate of R24 increases with the increase of the $\mathrm{n}$-dodecane mixing ratio, thus forming more $\mathrm{H}$ and promoting the production of more $\mathrm{O}$ and $\mathrm{OH}$ radicals in the reaction $\mathrm{R} 1$. This will promote the oxidation of the whole reaction system.

In order to explain the influence of the mixing ratio of methane and $\mathrm{n}$-dodecane on the ignition process, the reaction 
rates of production and consumption of $\mathrm{CH}_{4}$ and $n-\mathrm{C}_{12} \mathrm{H}_{26}$ were calculated at $\phi_{\text {total }}=1.0, T=900 \mathrm{~K}$, and $P=60 \mathrm{bar}$. The rates of production and consumption for methane are shown in Figure 15(a). The main reaction of methane consumption is $\mathrm{H}$ abstraction with $\mathrm{O}, \mathrm{H}$, and $\mathrm{OH}$ radicals including $\mathrm{R} 5$ $\left(\mathrm{CH}_{4}+\mathrm{H}=\mathrm{CH}_{3}+\mathrm{H}_{2}\right)$, $\mathrm{R} 96\left(\mathrm{CH}_{4}+\mathrm{OH}=\mathrm{CH}_{3}+\mathrm{H}_{2} \mathrm{O}\right)$, and $\mathrm{R} 97\left(\mathrm{CH}_{4}+\mathrm{O}=\mathrm{CH}_{3}+\mathrm{H}_{2} \mathrm{O}\right)$. The consumption of methyl and the formation of methane are mainly through the reaction R94 $\left(\mathrm{CH}_{3}+\mathrm{H}(+\mathrm{M})=\mathrm{CH}_{4}(+\mathrm{M})\right)$. It is obvious that the reaction rate increases with the increase of the methane mixing ratio, especially R96. The rates of consumption for n-dodecane are shown in Figure 15(b). The main consumption reactions of n-dodecane start from the initial stage, which explains the rapid decrease of the mole fraction of n-dodecane in Figure 10. R1211 $\left(\mathrm{n}-\mathrm{C}_{12} \mathrm{H}_{26}+\mathrm{H}=\mathrm{C}_{12} \mathrm{H}_{25}-6+\mathrm{H}_{2}\right), \mathrm{R} 1212\left(\mathrm{n}-\mathrm{C}_{12} \mathrm{H}_{26}+\mathrm{OH}=\mathrm{C}_{12}\right.$ $\left.\mathrm{H}_{25}-1+\mathrm{H}_{2} \mathrm{O}\right)$, and $\mathrm{R} 1213\left(\mathrm{n}-\mathrm{C}_{12} \mathrm{H}_{26}+\mathrm{OH}=\mathrm{C}_{12} \mathrm{H}_{25}-2+\mathrm{H}_{2} \mathrm{O}\right)$ are the main consumption reactions of $\mathrm{n}$-dodecane. Moreover, the total consumption rate of $n$-dodecane increases with the increase of the n-dodecane mixing ratio.

In a word, with the increase of n-dodecane content, the $\mathrm{H}$-abstraction reaction of $\mathrm{n}$-dodecane occurs first and the methane oxidation consumption is significantly reduced. Free radicals are formed in the initial stage of n-dodecane consumption, which improves the activity of the whole system and reduces the ignition delay time.

\section{Conclusions}

In order to study the ignition characteristics of a diesel pilot ignition nature gas dual-fuel engine, the ignition process of the methane-n-dodecane mixture was analyzed in detail from the perspectives of free radicals and fuel oxidation based on the simplified LLNL mechanism. The main conclusions are as follows:

(1) The ignition delay time was the shortest under different mole fractions of $n$-dodecane at different methane equivalence ratios and temperatures. In addition, the ignition delay time of the system increased with the increase of methane content because the addition of methane inhibited the decomposition of n-dodecane. When the initial pressure increases from 20 bar to 60 bar, the influence of the chemical effect of methane and ignition delay will be reduced, which may provide a valuable reference for dual-fuel engines, especially in the intake process and compression process of the engine.

(2) Methane/n-dodecane dual fuel exhibited a two-stage heat release phenomenon at an initial temperature of $700 \mathrm{~K}$. The results showed that the two-stage heat release time decreased with the increase of the $\mathrm{n}$-dodecane mixing ratio. Increasing the initial temperature and pressure of the mixture in the reaction system could shorten the ignition delay time of the dual fuel. Besides, the ignition process of the methane-n-dodecane mixture showed a certain NTC behavior. With the decrease of the n-dodecane mixing ratio, the NTC behavior of the total ignition delay time tended to be flat.
(3) With the increase of the $n$-dodecane mixing ratio, the time of methane complete consumption gradually decreased, which promoted methane consumption to a certain extent. In addition, the conversion rate of n-dodecane slowed down with the increase of methane mixing ratio, and the higher the methane mixing ratio, the more obvious the effect. When the $\mathrm{n}$-dodecane mixing ratio was lower, the effect of $\mathrm{n}$-dodecane content on the ignition delay time of the dual fuel was more significant. Furthermore, the effect of n-dodecane content on the ignition delay time of the dual fuel gradually decreased when the n-dodecane mixing ratio was greater than $50 \%$. The addition of methane decreased the final temperature of the methane/n-dodecane mixture system, which has a reference value for the practical dual-fuel engine, especially for the emission problem.

(4) By analyzing the reaction path, sensitivity, and reaction rate of methane and n-dodecane, it can be inferred that the reason for ignition delay was the free radical competition between $n$-dodecane and methane. The addition of $n$-dodecane increased the concentration of free radicals and promoted the oxidation of methane. Because the decomposition rate of n-dodecane was faster than that of methane, the ignition delay time decreased with the increase of the $\mathrm{n}$-dodecane mixing ratio.

This study can expand the theoretical basis of ignition delay phenomenon. The current research showed that the ignition process of methane-n-dodecane mixture had guiding significance for the research of dual-fuel engines. In addition, experimental studies on different NG and diesel components are also needed in order to provide more ignition process data.

\section{Data Availability}

The data are available in Supplementary Material.

\section{Conflicts of Interest}

The author declares that there are no conflicts of interest regarding the publication of this paper.

\section{Acknowledgments}

This work was supported by the National Natural Science Foundation of China (grant no. U1906232).

\section{Supplementary Materials}

Supplementary information associated with this article can be found in the online version. (Supplementary Materials)

\section{References}

[1] T. Korakiantis, A. M. Namasivayam, and R. J. Crookes, "Natural-gas fueled spark-ignition (SI) and compression-ignition (CI) engine performance and emissions," Progress in 
Energy and Combustion Science, vol. 37, no. 1, pp. 89-112, 2011.

[2] J. Fu, B. Deng, J. Liu et al., "Study of SI engine fueled with methanol vapor and dissociation gas based on exhaust heat dissociating methanol," Energy Conversion and Management, vol. 79, pp. 213-223, 2014.

[3] C. Yao, W. Pan, and A. Yao, "Methanol fumigation in compression-ignition engines: a critical review of recent academic and technological developments," Fuel, vol. 209, pp. 713-732, 2017.

[4] C. Chen, A. Yao, C. Yao, H. Wang, M. Liu, and Z. Li, "Selective catalytic reduction of nitrogen oxides with methanol over the (cobalt-molybdenum)/alumina dual catalysts under the diesel methanol dual fuel exhaust conditions," Chemical Engineering Science, vol. 211, Article ID 115320, 2020.

[5] J. Gao, D. Jiang, and Z. Huang, "Spray properties of alternative fuels: a comparative analysis of ethanol-gasoline blends and gasoline," Fuel, vol. 86, no. 10, pp. 1645-1650, 2007.

[6] X. Zhen, X. Li, Y. Wang, D. Liu, and Z. Tian, "Comparative study on combustion and emission characteristics of methanol/hydrogen, ethanol/hydrogen and methane/hydrogen blends in high compression ratio SI engine," Fuel, vol. 267, Article ID 117193, 2020.

[7] S. Akansu, Z. Dulger, N. Kahraman, and T. N. Veziroğlu, "Internal combustion engines fueled by natural gas? Hydrogen mixtures," International Journal of Hydrogen Energy, vol. 29, no. 14, pp. 1527-1539, 2004.

[8] J. Fu, J. Shu, F. Zhou, J. Liu, Z. Xu, and D. Zeng, "Experimental investigation on the effects of compression ratio on in-cylinder combustion process and performance improvement of liquefied methane engine," Applied Thermal Engineering, vol. 113, pp. 1208-1218, 2017.

[9] R. G. Papagiannakis, C. D. Rakopoulos, D. T. Hountalas, and D. C. Rakopoulos, "Emission characteristics of high speed, dual fuel, compression ignition engine operating in a wide range of natural gas/diesel fuel proportions," Fuel, vol. 89, no. 7, pp. 1397-1406, 2010.

[10] S. L. Kokjohn, R. M. Hanson, D. A. Splitter, and R. D. Reitz, "Fuel reactivity controlled compression ignition (RCCI): a pathway to controlled high-efficiency clean combustion," International Journal of Engine Research, vol. 12, no. 3, pp. 209-226, 2011.

[11] K. Amir-Hasan, P. Amin, and G. Mostafa, "The influence of fuel composition on the combustion and emission characteristics of natural gas fueled engines," Renewable and Sustainable Energy Reviews, vol. 38, pp. 64-78, 2014.

[12] R. G. Papagiannakis and D. T. Hountalas, "Experimental investigation concerning the effect of natural gas percentage on performance and emissions of a di dual fuel diesel engine," Applied Thermal Engineering, vol. 23, no. 3, pp. 353-365, 2003.

[13] M. Hinrich and B. Torsten, "Improvement of dual-fuel-engine technology for current and future applications," in Proceedings of the CIMAC Congress, Shanghai, China, 2013.

[14] G. McTaggart-Cowan, K. Mann, J. Huang et al., "Direct injection of natural gas at up to 600 bar in a pilot-ignited heavyduty engine," SAE International Journal of Engines, vol. 8, no. 3, pp. 981-996, 2015.

[15] W. Li, Z. Liu, and Z. Wang, "Experimental and theoretical analysis of the combustion process at low loads of a diesel natural gas dual-fuel engine," Energy, vol. 94, pp. 728-741, 2016.

[16] L. Zhu, B. Li, A. Li et al., "Effects of fuel reforming on largebore low-speed two-stroke dual fuel marine engine combined with EGR and injection strategy," International Journal of Hydrogen Energy, vol. 45, no. 53, pp. 29505-29517, 2020.

[17] S. Cordiner, M. Gambino, S. Iannaccone, V. Rocco, and R. Scarcelli, "Numerical and experimental analysis of combustion and exhaust emissions in a dual-fuel diesel/natural gas engine," Energy \& Fuels, vol. 22, no. 3, pp. 1418-1424, 2008.

[18] S. Choi, W. Park, S. Lee, K. Min, and H. Choi, "Methods for in-cylinder EGR stratification and its effects on combustion and emission characteristics in a diesel engine," Energy, vol. 36, no. 12, pp. 6948-6959, 2011.

[19] R. G. Papagiannakis and D. T. Hountalas, "Combustion and exhaust emission characteristics of a dual fuel compression ignition engine operated with pilot diesel fuel and natural gas," Energy Conversion and Management, vol. 45, no. 18-19, pp. 2971-2987, 2004.

[20] J. Liu, F. Yang, H. Wang, M. Ouyang, and S. Hao, "Effects of pilot fuel quantity on the emissions characteristics of a CNG/ diesel dual fuel engine with optimized pilot injection timing," Applied Energy, vol. 110, pp. 201-206, 2013.

[21] C. Abagnale, M. C. Cameretti, L. De Simio, M. Gambino, S. Iannaccone, and R. Tuccillo, "Combined numerical-experimental study of dual fuel diesel engine," Energy Procedia, vol. 45, pp. 721-730, 2014.

[22] S. K. Sunmeet and K. A. Subramanian, "Experimental investigations of effects of EGR on performance and emissions characteristics of $\mathrm{CNG}$ fueled reactivity controlled compression ignition (RCCI) engine," Energ Convers. Manage, vol. 130, pp. 91-105, 2016.

[23] R. G. Papagiannakis, D. T. Hountalas, C. D. Rakopoulos, and D. C. Rakopoulos, "Combustion and performance characteristics of a DI diesel engine operating from low to high natural gas supplement ratios at various operating conditions," SAE Technical Paper, 2008.

[24] F. Millo, F. Accurso, A. Piano, G. Caputo, and J. Hyvnen, "Experimental and numerical investigation of the ignition process in a large bore dual fuel engine," Fuel, vol. 290, Article ID 120073, 2021.

[25] S. Karimkashi, H. Kahila, O. Kaario, M. Larmi, and V. Vuorinen, "Numerical study on tri-fuel combustion: ignition properties of hydrogen-enriched methane-diesel and methanol-diesel mixtures," International Journal of Hydrogen Energy, vol. 45, no. 7, pp. 4946-4962, 2020.

[26] X. Zhang, C. Yuan, L. Zhou, W. Zhao, Z. Liu, and H. Wei, "Effects of initial temperature on ignition and flame propagation of dual-fuel mixture in mixing layer," Combustion and Flame, vol. 225, pp. 468-484, 2021.

[27] J. T. Farrell, N. P. Cernansky, F. L. Dryer, C. K. Law, D. G. Friend, and C. A. Hergart, "Development of an experimental database and kinetic models for surrogate diesel fuels," SAE Technical Paper, 2007.

[28] C. Gong, M. Jangi, and X.-S. Bai, "Large eddy simulation of n-dodecane spray combustion in a high pressure combustion vessel," Applied Energy, vol. 136, no. 31, pp. 373-381, 2014.

[29] H. Wang, Y. Ra, M. Jia, and R. D. Reitz, "Development of a reduced n-dodecane-PAH mechanism and its application for n-dodecane soot predictions," Fuel, vol. 136, pp. 25-36, 2014.

[30] Y. Ra and R. D. Reitz, "A combustion model for multicomponent fuels using a physical surrogate group chemistry representation (PSGCR)," Combustion and Flame, vol. 162, no. 10, pp. 3456-3481, 2015.

[31] F. Payri, J. M. García-Oliver, R. Novella, and E. J. PérezSánchez, "Influence of the n-dodecane chemical mechanism on the CFD modelling of the diesel-like ECN spray A flame 
structure at different ambient conditions," Combustion and Flame, vol. 208, pp. 198-218, 2019.

[32] X. Fu and S. K. Aggarwal, "Two-stage ignition and NTC phenomenon in diesel engines," Fuel, vol. 144, pp. 188-196, 2015.

[33] B. Tekgül, H. Kahila, O. Kaario, and V. Vuorinen, "Large-eddy simulation of dual-fuel spray ignition at different ambient temperatures," Combustion Flame, vol. 215, pp. 51-56, 2020.

[34] H. Kahila, A. Wehrfritz, O. Kaario, and V. Vuorinen, "Largeeddy simulation of dual-fuel ignition: diesel spray injection into a lean methane-air mixture," Combustion and Flame, vol. 199, pp. 131-151, 2019.

[35] H. Kahila, O. Kaario, Z. Ahmad et al., "A large-eddy simulation study on the influence of diesel pilot spray quantity on methane-air flame initiation," Combustion and Flame, vol. 206, pp. 506-521, 2019.

[36] A. R. Khan, M. R. Ravi, and A. Ray, "Experimental and chemical kinetic studies of the effect of $\mathrm{H}_{2}$ enrichment on the laminar burning velocity and flame stability of various multicomponent natural gas blends," International Journal of Hydrogen Energy, vol. 44, no. 2, pp. 1192-1212, 2019.

[37] Mechanical and Aerospace Engineering (Combustion Research), University of California at San Diego, ChemicalKinetic Mechanisms for Combustion Applications, San Diego Mechanism web page, 2016, http://combustion.ucsd.edu.

[38] G. P. Smith, D. M. Golden, M. Frenklach et al., "GRI-Mech 3.0. URL," 1999, http://www.me.berkeley.edu/gri_mech.

[39] H. Wang, X. You, A. V. Joshi et al., "USC mech version IIhigh-temperature combustion reaction model of $\mathrm{H}_{2} / \mathrm{CO} / \mathrm{C} 1$ C4 compounds," http://ignis.usc.edu/USC_Mech_II.htm.

[40] E. Gimeno-Escobedo, A. Cubero, J. S. Ochoa, and N. Fueyo, "A reduced mechanism for the prediction of methane-hydrogen flames in cooktop burners," International Journal of Hydrogen Energy, vol. 44, no. 49, pp. 27123-27140, 2019.

[41] S. M. Sarathy, C. K. Westbrook, M. Mehl et al., "Comprehensive chemical kinetic modeling of the oxidation of 2methylalkanes from $\mathrm{C}_{7}$ to $\mathrm{C}_{20}$," Combustion and Flame, vol. 158, no. 12, pp. 2338-2357, 2011.

[42] T. Lu and C. K. Law, "A directed relation graph method for mechanism reduction," Proceedings of the Combustion Institute, vol. 30, no. 1, pp. 1333-1341, 2005.

[43] P. Pepiot, "An efficient error-propagation-based reduction method for large chemical kinetic mechanisms," Combustion Flame, vol. 154, no. 1-2, pp. 67-81, 2008.

[44] Reaction Workbench, ANSYS CHEMKIN 17.0, Reaction Workbench, San Diego, CA, USA, 2016.

[45] Reaction Workbench, ANSYS CHEMKIN 17.0, ANSYS Reaction Design, San Diego, CA, USA, 2016.

[46] S. S. Vasu, D. F. Davidson, Z. Hong, V. Vasudevan, and R. K. Hanson, "n-Dodecane oxidation at high-pressures: measurements of ignition delay times and $\mathrm{OH}$ concentration time-histories," Proceedings of the Combustion Institute, vol. 32, no. 1, pp. 173-180, 2009.

[47] K. Kumar and C. J. Sung, "Laminar flame speeds and extinction limits of preheated $n$-decane $/ \mathrm{O}_{2} / \mathrm{N}_{2}$ and $n$-dodecane/ $\mathrm{O}_{2} / \mathrm{N}_{2}$ mixtures," Combust Flame, vol. 151, no. 1-2, pp. 209-224, 2007.

[48] C. Ji, E. Dames, Y. L. Wang, H. Wang, and F. N. Egolfopoulos, "Propagation and extinction of premixed $\mathrm{C}_{5}-\mathrm{C}_{12}$ n-alkane flames," Combustion and Flame, vol. 157, no. 2, pp. 277-287, 2010.

[49] X. Hui and C.-J. Sung, "Laminar flame speeds of transportation-relevant hydrocarbons and jet fuels at elevated temperatures and pressures," Fuel, vol. 109, pp. 191-200, 2013.
[50] D. M. Manias, E. A. Tingas, C. E. Frouzakis, K. Boulouchos, and D. A. Goussis, "The mechanism by which $\mathrm{CH}_{2} \mathrm{O}$ and $\mathrm{H}_{2} \mathrm{O}_{2}$ additives affect the autoignition of $\mathrm{CH}_{4}$ /air mixtures," Combustion and Flame, vol. 164, pp. 111-125, 2016.

[51] E. L. Petersen, J. M. Hall, S. D. Smith, J. D. Vries, A. Amadio, and M. W. Crofton, "Ignition of lean methane-based fuel blends at gas turbine pressures," in Proceedings of the ASME Turbo Expo 2005: Power for Land, Sea, and Air, Reno, NV, USA, June 2005.

[52] W. K. Metcalfe, S. M. Burke, S. S. Ahmed, and H. J. Curran, “A hierarchical and comparative kinetic modeling study of $\mathrm{C}_{1}-\mathrm{C}_{2}$ hydrocarbon and oxygenated fuels," International Journal of Chemical Kinetics, vol. 45, no. 10, pp. 638-675, 2013.

[53] X. J. Gu, M. Z. Haq, M. Lawes, and R. Woolley, "Laminar burning velocity and markstein lengths of methane-air mixtures," Combust. Flame, vol. 121, no. 1-2, pp. 41-58, 2000.

[54] G. Rozenchan, D. L. Zhu, C. K. Law, and S. D. Tse, "Outward propagation, burning velocities, and chemical effects of methane flames up to $60 \mathrm{~atm}$," Proceedings of the Combustion Institute, vol. 29, no. 2, pp. 1461-1470, 2002.

[55] Combustion Network Engine, Combustion Research Facility, Sandia national laboratories, Livermore, CA, USA, 2019, https://ecn.sandia.gov.

[56] R. Li, J. M. Herreros, A. Tsolakis, and W. Yang, "Chemical kinetic study on ignition and flame characteristic of polyoxymethylene dimethyl ether 3 (PODE3)," Fuel, vol. 279, Article ID 118423, 2020.

[57] M. Li, X. Liu, T. Zhang, and Q. Zheng, "A kinetic study on the effects of methane substitution on the ignition of n-heptane/ air mixture," Journal of the Energy Institute, vol. 92, no. 3, pp. 459-473, 2019. 